\title{
The water resources of tropical West Africa: problems, progress, and prospects
}

\author{
Christopher E. Ndehedehe ${ }^{1}[\mathbb{C}$
}

Received: 16 September 2018 / Accepted: 30 January 2019 / Published online: 7 February 2019

(C) Institute of Geophysics, Polish Academy of Sciences \& Polish Academy of Sciences 2019

\begin{abstract}
West Africa plays key roles in global climate and shows one of the strongest variations in hydro-climatic conditions. As it turns out, the region appears to be underrepresented in the existing compendium of Earth science and hydrology-focused journal papers when it comes to significant discussion on terrestrial hydrology and freshwater science. This prominent gap is largely precipitated by increasing number of constraints that include lack of considerable and robust investments in gauge measurements for meteorological and hydrological applications, poor funding of research institutions and other disincentives, among other factors. In this manuscript, the challenges and problems in large-scale terrestrial hydrology-focused investigation in West Africa are reviewed. Using a dossier of some recent contributions in the field of remote sensing hydrology, this review also highlights some of the progress in terrestrial hydrology and the opportunities that exist for hydro-geodetic research in West Africa that leverage on sustained investments in satellite geodetic missions. It is noted that West Africa is still a pristine environment for hydrology-focused research and can benefit from recent advancements in sophisticated space agency programs such as the Gravity Recovery and Climate Experiment, which undoubtedly has revolutionized terrestrial hydrology research around the world for nearly two decades. Given the poor density of gauge stations and limited ground observations, hydrological research in West Africa is expected to benefit more from independent space observations and multi-resolution data. This is because the lack of sufficient in-situ data for the parameterizations and adequate initialization of outputs from hydrological models and reanalysis data for hydrological applications results in poor representation of the West African land surface and hydrological state variables. To further improve our contemporary understanding of West Africa's terrestrial hydrology, the continued evaluation/validation of these observations and space-borne measurements is advocated.
\end{abstract}

Keywords Terrestrial hydrology $\cdot$ Droughts $\cdot$ Rainfall $\cdot$ River discharge $\cdot$ Climate variability

\section{Introduction}

Some new metrics based on the framework of the intersectoral impact model intercomparison project (ISI-MIP) suggest a $40 \%$ increase in the number of people living under absolute water scarcity, up from $15 \%$ of the global population with a severe decrease in water resources (Schewe et al. 2013). Whereas humanity in general takes water for granted owing to its obvious simplicity (see Falkenmark and Lundqvist 1998), future simulations of freshwater availability show increased water stress in the coming decades owing to population rise

Christopher E. Ndehedehe

c.ndehedehe@griffith.edu.au

1 Australian Rivers Institute and School of Environment and Science, Griffith University, Nathan, Queensland 4111, Australia and the impacts of unmitigated climate change. For instance, total water withdrawals as at the year 2000 amounted to $8.4 \%$ of global water resources, and this amount is expected to increase up to $12.2 \%$ (i.e., between 4600 and $5800 \mathrm{~km}^{3}$ /year) by 2025 (Shiklomanov 2000). In a study of global water resources, Vörösmarty et al. (2000) projected estimate of global water use by 2025 puts the value at $4700 \mathrm{~km}^{3} /$ year. Regarding water scarcity projections, about $57 \%$ and $69 \%$ of the world's population are estimated to live in countries facing high water stress by 2025 and 2075, respectively (Alcamo et al. 1997). The argument that considerable portion of the world's population will face water stress by 2025 , be it moderate or severe may be somewhat polarized in terms of projected estimates, given the uncertainties and substantial differences in model outputs (e.g., Gleick 2000; Kuylenstierna et al. 1997). Nevertheless, documentary evidence suggests that water shortages (or rather scarcity) will be one of the world's most 
pressing challenges in the twenty-first century (e.g., Freitas 2013; Rijsberman 2006; Vörösmarty et al. 2005; Kuylenstierna et al. 1997; Alcamo et al. 1997).

From a contemporary perspective, the rise in drought frequency across the globe in the last few decades (see Ndehedehe et al. 2019; Spinoni et al. 2014; van der Molen et al. 2011) strengthens this argument of anticipated water stress. Considering the notable and often repeated extreme climatic conditions in Africa, the aforementioned projections and indicators of water stress could have significant negative impacts on a considerable proportion of Africa's agricultural biomes, livelihood, and ecosystem services. Arguably, the region's lack of preparedness, limited resources, and plausible policy responses increases its vulnerability to such impacts. It has been reported that about $25 \%$ of people living in Africa are already experiencing water stress, while an estimated $13 \%$ are direct recipients of drought-related stress once each generation (see Vörösmarty et al. 2005). Because of such concerns and the cumulative impacts of climate variability on water availability, stormwater harvesting was recently (see Fisher-Jeffes et al. 2017) suggested in South Africa as possible alternative water resource that could supplement traditional urban water supplies and improve water security. Water scarcity by itself represents one of the characteristics (e.g., degree of scarcity) that could make water a potential source of strategic rivalry (Gleick 1993). This is true for Texas, Africa, and other regions where water-related conflicts and the impacts of water scarcity on national security have been identified (Freitas 1993, Gleick 2000, 2013 ). As further mentioned in Freitas (2013), the increasing pressure on water resources in West Africa and other regions of Africa is a potential source of local agitations and interstate tensions that may eventually lead to armed conflicts. But more importantly, despite all of the recurrent climatic, hydrological, and environmental changes that affect the stability of regional income and livelihood, little is known about the terrestrial water systems of West Africa. This limited understanding of the region's hydrology has been attributed to an increasing number of constraints that include lack of sufficient observational networks and/or decline of in situ observations for large-scale hydrological research in West Africa. In this manuscript, critical challenges and the progress made in large-scale terrestrial hydrology-focused research over West Africa are reviewed. In the next section, an overview of the current state of knowledge in West Africa's terrestrial hydrology is indicated while highlighting the specific objectives of the manuscript.

\section{The terrestrial hydrology of West Africa}

\section{Water resources}

West Africa is enriched with numerous surface water resources (rivers, estuaries, lakes, reservoirs), including major rivers such as the Niger, Senegal, Gambia, and Lake Chad. These rivers take their sources in tropically wet major groundwater basins and regions with considerable amount of annual rainfall (Fig. 1a, b). In addition to the Benue and the Volta river systems (Black and White Volta rivers and Oti), these river systems among others drain the West African subregion. At basin or water management scale, most of West Africa's water resources are shared by participating riparian countries from about 28 transboundary river basins. Some regional and national institutions exist in these river basins that oversee the management and development of water resources. Significant among them is the GLOWA Volta Project, which is saddled with the responsibility of understanding the impact of global change on the use and availability of water resources in the Volta Basin (e.g., de Giesen et al. 2007). In light of the highly variable climatic conditions of West Africa, the West African Science Service Centre on Climate Change and Adapted Land Use (WASCAL, https://www.wascal.org/about-wascal/welcome-to-wasca $1 /$ ) is another regional initiative that provides researchbased solutions to enhance the resilience of human and environmental systems to the impacts of climate change. This is achieved through capacity building and provision of research infrastructure for climate studies in several West African countries.

As a little caveat to the study area definition, it should be noted that this review is over West Africa, a region defined by the Economic Community of West African States as covering about sixteen countries, and includes Chad and Cameroon. However, given that the latter is a country in Equatorial Africa, this study also takes advantage of the prominent gap in the knowledge of climate variability and its impacts on hydrological changes in Central Equatorial African countries (i.e., the Congo Basin) to extend this synopsis to include the region. These two regions called tropical West Africa which is hereafter referred to as West Africa in the manuscript for simplicity and convenience (Fig. 1a). In terms of water availability, the Guinea Coast countries and those in the Congo Basin exceed other regions of West Africa (Fig. 1b). As with Guinea Coast region, the Congo Basin has numerous networks of surface water resources (Fig. 1a). Annual rainfall amount in the Guinea Coast area is nonetheless the highest (Fig. 1b) and shows the strongest spatiotemporal variability as opposed to the Congo Basin and the Sahel 


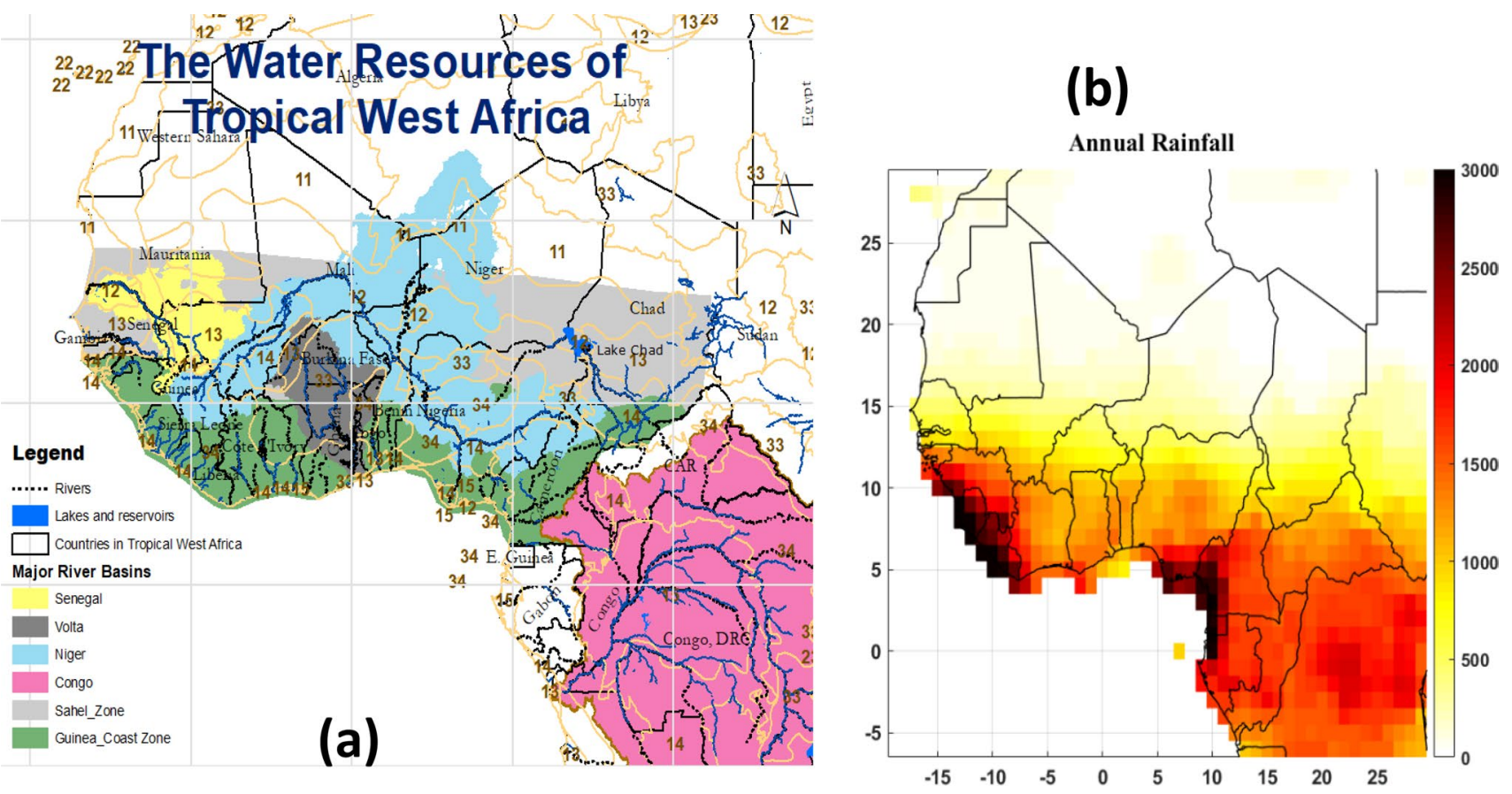

Fig. 1 Map showing some of the water resources in tropical West Africa (i.e., areas that include Central Equatorial Africa or Congo Basin). a The hydrological units (rivers, lakes, and groundwater aquifers) and the main river basins, which include Niger, Volta, Congo, and Senegal. The Congo (tulip pink) and Niger (sky blue) river basins are considerably large and apparently the most significant and prominent basins in the region owing to the two major rivers (Niger and Congo) that provide numerous ecosystem services. The aquifers (brown contour lines) are characterized in terms of numbers; for example, the numbers ranging from 11 to 15 are found in major groundwater basins, while the numbers 33 and 34 on the map are those found in local and shallow aquifers. The aquifer maps and some hydrological units (river distribution networks) are those of Worldwide Hydrogeological Mapping and Assessment Programme. b The mean annual rainfall over tropical West Africa based on the Global Precipitation Climatology Center (GPCC) precipitation for the period between 1901 and 2014
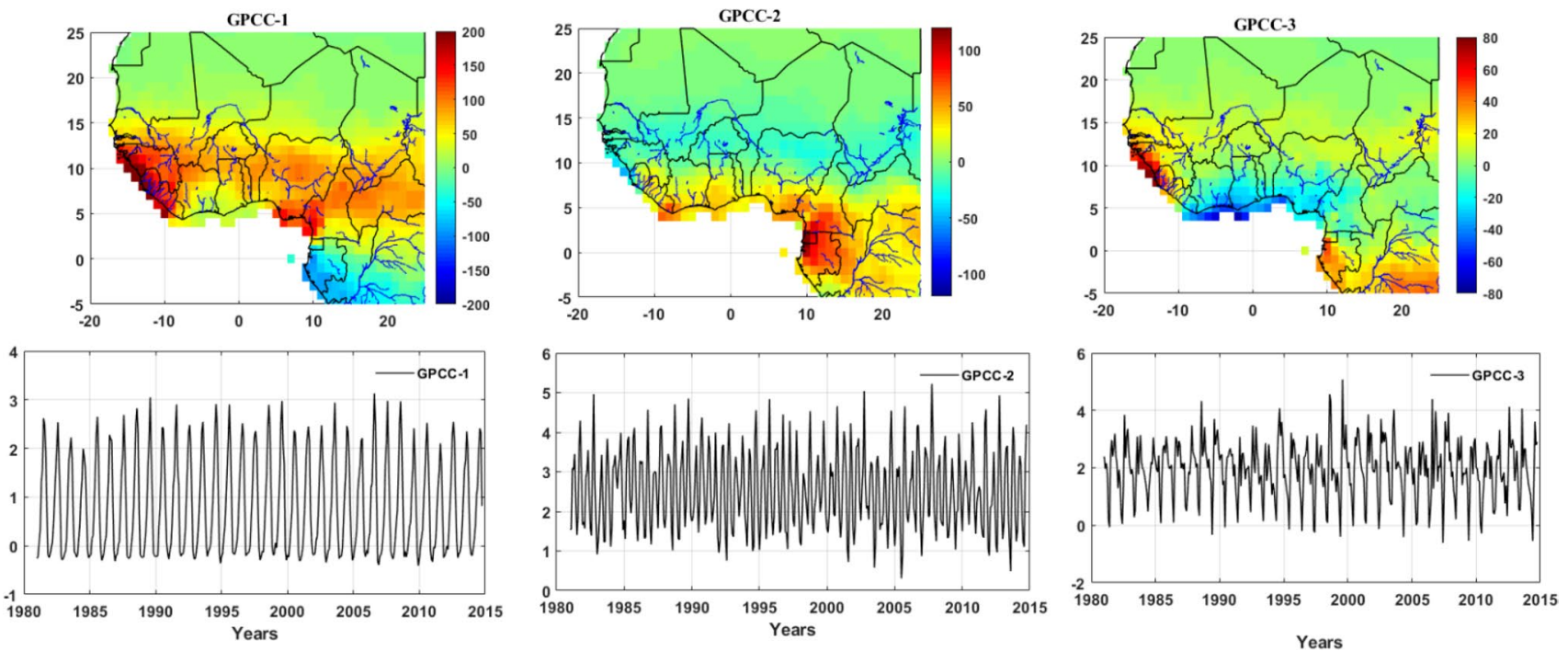

Fig. 2 Statistical decomposition of GPCC-based precipitation (19812014) over tropical West Africa using principal component analysis (e.g., Preisendorfer 1988). The EOFs (top) are loadings showing spatial patterns of variations in precipitation over TWA, while the corresponding PCs (bottom) are temporal variations, which are normal- ized using their standard deviation to be unitless. The total variability accounted for by the three leading orthogonal modes is $60 \%, 10 \%$, and 5\% for GPCC-1, GPCC-2, and GPCC-3, respectively. The blue lines on the spatial patterns (top) are river networks and reservoirs 
regions (Fig. 2). The leading orthogonal modes of rainfall over West Africa as shown in Fig. 2 provide an overview of freshwater availability in the region. For example, the regions with stronger spatial loadings (patterns) in rainfall (GPCC-1, Fig. 2) coincide with areas characterized by strong annual amplitudes of rainfall (Fig. 1b), and where strong variability in terrestrial water storage has been observed (Ndehedehe et al. 2016b). The corresponding temporal patterns of leading modes of rainfall over the region are largely characterized by interannual (GPCC1 , which accounts for $60 \%$ of total variability), bimodal (GPCC-2), and seasonal variations (GPCC-3) and indicate that Liberia and Guinea receive the most rainfall (Fig. 2). Despite the enormous water resources of these regions (Guinea Coast and the Congo Basin), their increasing vulnerability to several drought intensities in recent times (e.g., Andam-Akorful et al. 2017; Ndehedehe et al. 2016c, 2019) tends to strengthen the argument for the wet getting drier paradigm.

With increasing need of freshwater for several ecosystem functions, water availability is now a concern for some regions in both West and Central Africa that are predominantly semiarid. This is evidenced, for example, in the Lake Chad basin's interest in transferring the surface water resources of the Congo Basin to nourish the nearly desiccated Lake Chad (e.g., Ndehedehe et al. 2016b; Lemoalle et al. 2012). There are ongoing public discourse and debates as to the feasibility of this proposed project. However, the eco-hydrological and cultural implications of this project, in addition to the legal requirements, institutional and other policy solutions, are key issues to be addressed. The enormous shared freshwater resources in the region, which have reduced considerably in the past two decades (e.g., Freitas 2013) as exemplified by the Lake Chad, could exacerbate local tensions due to growing water scarcity and increased competition among riparian countries. To help address some of the problems related to water resources in the region, several regional water initiatives (e.g., Volta Basin Authority), partnerships (e.g., West African Water Partnership), and bilateral cooperations (e.g., agreement between Niger and Benin on the development of surface schemes) (see https:// www.oecd.org/swac/publications/38409569.pdf) were inaugurated. Ultimately, these institutions and other more recent collaborative efforts with international agencies "Current state of hydrology research" section) are some regional and institutional progress made for sustainability and effective management of water resources.

\section{Hydro-climatic issues}

After the notable climatic shifts of the 1970s and 1980s in most West African catchments, some ecological and hydrological impacts were reported. Of note is the loss and contraction of major freshwater bodies such as the Lake Chad whose surface extent declined by about $90 \%$ (Fig. 3). Widespread desertification and degradational transitions in natural vegetation and land use through land clearing and logging (e.g., Knauer et al. 2014; Tucker et al. 1991) were other notable eco-hydrological events that ensued. Few pioneering hydrological papers in addition showed that despite observed precipitation decline during the period, some Sahelian catchments witnessed paradoxical increase in groundwater resources due to changes in soil characteristics and vegetation cover (see, e.g., Mahé and Paturel 2009; Favreau et al. 2009; Séguis et al. 2004; Leduc et al. 1997, 2001). Whereas the efforts to unravel such complex hydrological processes are ongoing (e.g., Gal et al. 2017; Descroix et al. 2009), it has been argued that the tripartite relationship between climate, rural society, and the environment drives land cover changes in the West African Sahel, which in turn drive the distribution of rainfall and water resources in general (Paturel et al. 2017). Moreover, as indicated in global climate projections, the impacts of climate change are expected to have direct and profound negative effects on freshwater availability (see, e.g., Tall et al. 2016; Prudhomme et al. 2014; Schewe et al. 2013). Recently, it has been shown that indices of oceanic variability (e.g., El Niño-Southern Oscillation-ENSO) and sea surface temperature anomalies of the nearby oceans impact on the dynamics and distributions of land water storage in West Africa (e.g., Ndehedehe et al. 2017b). However, a more recent climate projection suggests a climatic shift to drier climate in the 2050 and 2080s in West Africa, largely characterized by increase in drought-prone areas (Gizaw and Gan 2017).

West Africa is one of the world's poorest regions with increasing population and intensity in climate extremes. That population growth and freshwater variability are now significant measures of economic development (e.g., Hall et al. 2014; Brown and Lall 2006), West Africa, under a climate change scenario, perhaps could be the most vulnerable to severe water stress and human-modified drought in the nearest future. As most agricultural goods are produced in regions that are vulnerable to water-related impacts, this will have massive implications not just on the economy of West Africa but other regions of the world that indirectly consume the water resources of West Africa. This arguably emphasizes the strategic importance of West African countries in global food production chain on the one hand. On the other hand, it suggests that the scale of the problem is global.

\section{Current state of hydrology research}

Advancements in space agency programs, developments in Earth observation, and its growing applications in hydrology are well documented for other regions of the world. 


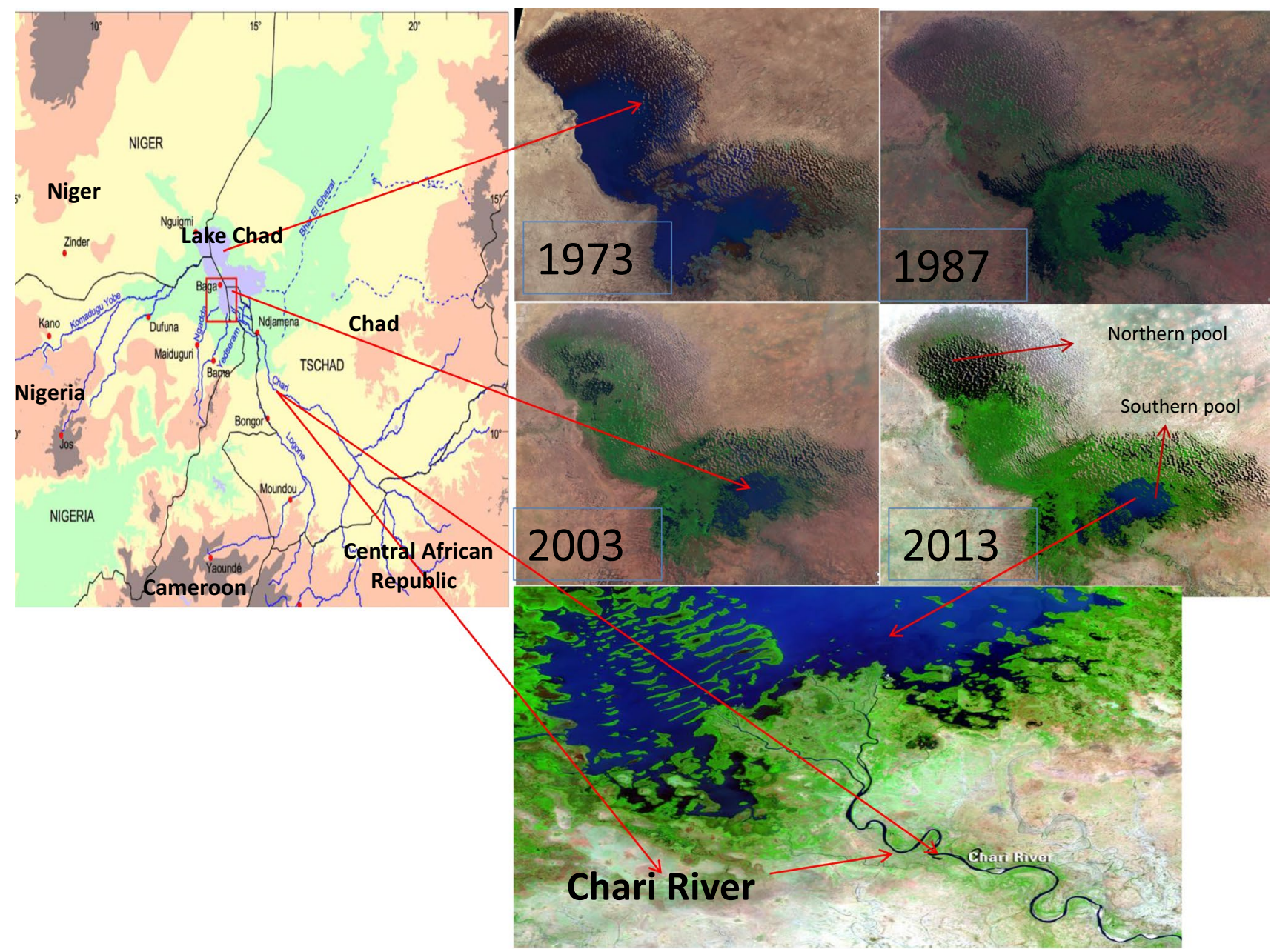

Fig. 3 The spatial and temporal changes in Lake Chad surface area as shown by Landsat imageries for 1973, 1987, 2003, and 2013. The blue lines on the map (left) show the river networks within the basin. The present Lake Chad shows two segmented pools with the northern

However, West Africa's terrestrial hydrology is conspicuously underrepresented in the literature and in fact the least studied. As oppose to other regions of the world with detailed diverse applications of remote sensing data to study hydrological processes (e.g., McCabe et al. 2017; Alsdorf et al. 2016), discipline-specific studies in West Africa that delivers on the terrestrial hydrology and impacts of climate variability on water resources are undeniably limited and somewhat lacking in the volumes of existing studies and catalog of hydrological journals. Extreme climatic conditions (i.e., droughts) of the last 3-4 decades had enormous negative impacts on West Africa 's freshwater resources (e.g., Freitas 2013; Wald 1990). Yet the representation of the state of hydrological knowledge in West Africa suggests there are still considerable gaps in knowledge vis-à-vis global perception of Earth science research. One particular area with considerable gap in knowledge in West Africa is pool completely dried up during drought periods (right). The map as adapted from Ndehedehe et al. (2016b) shows the impact of climate change resulting in morphological changes, gradual desiccation, and reduction in Lake Chad's freshwater during the last four decades

its groundwater and aquifer systems. Although there is some historic evidence regarding groundwater bore measurements and well hydrographs in some locations in the Sahel (e.g., Henry et al. 2011), generally a considerable proportion of West Africa is either lacking hydro-geological data or having sparsely distributed gauged stations and/or rarely monitored well locations. However, some collaborative efforts between the German research program on the global water cycle (GLOWA) and the Integratives Management-Projekt für einen Effizienten und Tragfähigen Umgang mit Süßwasser in West Afrika (IMPETUS) initiative and those of AMMA-CATCH and GHYRAF ("Limited observational networks" section) on water resources development are significant progress made in the region (e.g., Ndehedehe 2017; Andam-Akorful et al. 2017). Be it groundwater or aquifer systems, West Africa seems to be generally dependent on information from external or international agencies like the 
World-wide Hydrogeological Mapping and Assessment Programme (Fig. 1a) and the global groundwater information system, among others.

Furthermore, the massive changes in land cover and land use patterns of West Africa in the last 5 decades (e.g., Li et al. 2007) had significant impacts on its terrestrial hydrology causing an imbalance in water budget and complex hydrological processes (see, e.g., Favreau et al. 2009; Séguis et al. 2004; Li et al. 2007; Leduc et al. 1997). However, our contemporary understanding of West Africa's terrestrial hydrology is insufficient and somewhat flagged with inconclusive discourse. Despite the emergence of large-scale hydrological models, the interplay between terrestrial water fluxes and human actions, which has not been fully explored (see Wada et al. 2017), contributes to the limited use of hydrological models for freshwater investigations. Whereas the representation of anthropogenic contributions in global hydrological models is challenging as argued by Wada et al. (2017), the aftermath of water resources assessments from such models for West Africa where various human actions and changes in soil properties drive surface hydrology (e.g., Gal et al. 2017; Favreau et al. 2009) would be somewhat skewed and characterized by inconsistent results. This is because of the failure of hydrological models to faithfully and realistically account for the human dimension that also triggers considerable changes in terrestrial water systems. Therefore, if peer-reviewed science papers represent a state of knowledge and an opportunity to highlight scientific findings based on new or revised data and conducting research in regions with limited knowledge (Alsdorf et al. 2016), this is therefore a clarion call to remotely sensed, large-scale terrestrial hydrology-focused investigation in West Africa. The accentuation of such call is predicated on three vital factors: (i) the argument that most drainage basins in West Africa are located in hydrologically unfavorable environments (see Anyadike 1992), (ii) West Africa plays key roles in global climate and shows one of the strongest variations in climatic conditions, and (iii) the strong marginalization of West Africa in Earth science and hydrology research. Hence, opportunities for hydro-climatic research will bring Africa and its subregions to the fore in leading English-language journals that explore global changes in hydrology.

From a contemporary, large-scale innovative context, hydrological research is still much rather at the embryonic stage in Africa. For prominent river basins like the Congo, despite having a long history of hydrological measurements (Alsdorf et al. 2016), there is a considerable decline in the knowledge of the basin's hydrology as opposed to the last four decades. While this review highlights some of the reasons for such limited understanding in recent times, the focus on West Africa is meant to stimulate research interest in other African subregions and provide relevant insights that will improve our understanding of continental freshwater dynamics. Hence, a synthesis of some recent contributions in the fields of hydrology and water resources in the region are identified and used to (i) assess the knowledge gaps and significant challenges in hydrological research, (ii) examine contemporary perspectives on hydrological processes and drivers of land water storage, (iii) discuss progress and innovative approaches to large-scale freshwater monitoring, and (iv) articulate new and impressive perspectives on the characterization of space-time evolutions of extreme weather events and key hydrological metrics. Among several other considerations, for example, addressing the 'data problem' and the complementary perspectives on hydrological controls on surface vegetation dynamics, this review further highlights the newly introduced hydro-geodetic approaches to terrestrial hydrology and its potential in the assessment of the region's surface and subsurface hydrology.

\section{Knowledge gaps and challenges to large-scale hydrological research}

\section{Hydrological variability}

Generally in Africa, hydrological variability and several drought episodes have amazingly large negative impacts on freshwater resources, biodiversity, food security, and health among other factors. These deleterious impacts hamper economic development, e.g., low gross domestic product (e.g., Brown and Lall 2006), and contribute to increased poverty in one of the world's poorest continent. Arguably, reoccurring drought episodes of the 1970s and 1980s, and the incessant impacts of climate variability on the socioeconomic systems of West Africa were major triggers that led to the plenitude of climate research at the time. The various aspects of these studies focused mainly on analyzing multiple climate variables such as precipitation, runoff, soil moisture, temperature, and zonal winds, among others (see, e.g., Ndehedehe et al. 2016c; Hua et al. 2016; Tarhule et al. 2015; Nicholson 2013; Mohino et al. 2011; Paeth et al. 2012; Conway et al. 2009; Ali and Lebel 2009; Boone et al. 2009). Moreover, historical gauge data, outputs from global and regional climate models (i.e., GCMs and RCMs), and a host of optical remote sensing data, have been widely used in several hydro-climatic research at all levels (county level, region-specific, and large scales) in the region. These studies as highlighted in subsequent sections heavily explored and diagnosed the mechanisms of meteorological patterns and how it drives other fluxes (runoff and evapotranspiration) and land state variables (soil moisture). There are still knowledge gaps nonetheless particularly in areas regarding large-scale temporal and spatial dynamics of terrestrial water storage (TWS), and the impacts of both climate change and water resources development (e.g., irrigation schemes and 
dam constructions for hydropower) on the hydrological systems of West Africa. From a hydrological stand point, water development schemes (e.g., Lake Volta) impact on natural hydrological variabilities, making it difficult to understand the influence of climate on hydrological conditions. A typical example is the Volta Basin where human water management is considered a significant driver in the dynamics of surface water (e.g., Ndehedehe et al. 2017a; Ferreira and Asiah 2015). Further, several scientific reports (e.g., Ndehedehe et al. 2018b; Andam-Akorful et al. 2017; Panthou et al. 2014; Todd et al. 2011; Sheffield and Wood 2008) have outlined exhaustively the influence of global climate and some oceanic hot spots on precipitation changes in West Africa. The influence of climate variability and low-frequency variability that are connected to slow oceanic and climate oscillations from global SST anomaly on the region's TWS has only been recently reported (e.g., Ndehedehe et al. 2018b; Andam-Akorful et al. 2017). Such influence modulates hydrological processes and provides significant control on the spatial and temporal distributions of regional changes in TWS and other water budget quantities (e.g., runoff), resulting in increased acceleration of the water cycle.

Moreover, poor understanding of hydrological variability poses significant challenge to risk management and the prediction of extreme weather events (Hall et al. 2014). The knowledge of hydrological variability in this most financially and climatically challenged region of the world is critical. This is true as variations in hydrology have been identified as one of the key variables causing disparity in the level of economic growth among nations, given that it represents a significant challenge to food security and infrastructure development in the world's poorest regions (see Hall et al. 2014; Brown and Lall 2006). For instance, before the unprecedented droughts of 1980s, the surface water of Lake Chad played significant role in the economy and stability of the region. Apart from other numerous surface water developments for agricultural purposes, Lake Volta and the Kainji Dam are dedicated income-generating hydropower schemes, which sometimes are affected by drought events (e.g., Ndehedehe et al. 2016a, c).

In West Africa, water-related knowledge and innovative technologies are not in the front lines of academic research institutions and government agenda, owing to poor funding and other disincentives. Consequently, the vulnerability of the region to the impacts of climate change (Fig. 3) will continue to grow with ripple effects through its socioeconomic systems. Observed devastating extremes in the climate of West Africa raise some concerns not just for water availability but also for a number of issues that include food security, health, policy and risk management strategies, and socioeconomic challenges (e.g., migration, GDP, etc.). The trajectory of future changes in hydrological conditions and water management practices are complex and will influence agricultural systems in terms of adaptation measures and mitigation strategies (see, e.g., Paolino et al. 2012; Roudier et al. 2011; Falloon and Betts 2010). Despite the tragedies of frequent extremes in climatic conditions over West Africa, understanding hydrological variability is a wise choice that can unlock sustainable pathways and help mitigate the impacts of hydrological changes on economic growth.

\section{Limited observational networks}

Knowledge gaps in large-scale TWS dynamics and the impacts of climate on the hydrology of West Africa exist, primarily because of limited or lack of observational networks to provide the current state of hydrological information. Gauge stations for rainfall and river discharge measurements are in decline globally (e.g., Alsdorf et al. 2007; Alsdorf and Lettenmaier 2003; Lettenmaier 2005). It is even worse in non-industrialized nations such as the African subregion where the gauge networks are not just extremely sparse, discontinuous, and lacking, but their density falls far below the WMO (World Meteorological Organization) guidelines (e.g., Vörösmarty et al. 2001). As further mentioned in Vörösmarty et al. (2005), the routine reporting of African river discharge to relevant climate agencies such as the WMO declined by $90 \%$ since 1990 . Despite some investments in gauge measurements for meteorological and hydrological applications in some parts of West Africa, many subregions have little or no history of hydrological measurements. This is largely attributed to incessant political instabilities, lack of civilization (i.e., in terms of investing in research), and the costs and logistics implications for the installation of gauges to characterize flow dynamics. The paucity of primary baseline data in West Africa is major challenges that may further create a huge hydro-climatic information gap. This could restrict the availability of information regarding future projections of floods and droughts, in addition to the interannual fluctuations in streamflow in West Africa (Roudier et al. 2014).

The lack of capacity to face the future challenges of climate change impact on water resources, owing to sparse observational record in some gauged river basins, is intensified by political concerns, legal and institutional constraints that have hindered the acquisition of existing data for scientific purposes. Research institutions find it difficult to engage in regional water management and transboundary water sharing conversations because hydro-climatic data from national archives and government repositories are frequently withheld, mostly for political and security reasons. This could only be more damaging for West African countries where water sharing across political boundaries is vastly enormous. Further, the African Monsoon Multidisciplinary Analysis-Couplage Atmosphere Tropicale Cycle Hydrologique (AMMA-CATCH, e.g., Lebel et al. 2009) 
and Gravity and Hydrology in Africa (GHYRAF, Hinderer et al. 2009) projects are few among the significant initiatives that are primarily dedicated to studying land surface conditions in West Africa and other African regions through monitoring of hydro-climatological and ecological changes. However, whereas the AMMA-CATCH networks are highly insufficient with presence in only three countries of West Africa, the GHYRAF project is sandwiched between poor funding and transboundary issues (Ndehedehe et al. 2016a). Increased observational networks are critical for the proper initialization of numerical weather prediction models and monitoring climate variability in West Africa (Jenkins et al. 2002). But as indicated in some reports (see, e.g., Ndehedehe et al. 2016a; Todd et al. 2011; Farnsworth et al. 2011; Conway et al. 2009), the paucity of high-quality baseline data remains a major constraint to understanding the climatic influence on changes in the hydrological cycle over the region.

As argued by Alsdorf et al. (2007), gauge observations such as those from river stage are incapable of large-scale monitoring of hydrological conditions. This is because of the physics of water flow across floodplains and wetlands, and since gauge networks essentially provide a one spatial dimension information about the spatial dynamics of surface water extent. For some of these reasons and those presented by Alsdorf et al. (2003) in a related study, large-scale dynamics in surface waters (lakes, wetlands, rivers, reservoirs) are generally unknown. Understanding changes in the hydrological cycle over West Africa would not be possible without large-scale measurements that allow the estimations of the temporal and spatial dynamics of hydrological quantities. Apparently, developments in climate models (e.g., Erfanian et al. 2016; Washington et al. 2013; Otto et al. 2013; Mohino et al. 2011; Cook and Vizy 2006; Li et al. 2005; Koster et al. 2004; Giannini et al. 2003; Lebel et al. 2000), land surface parameterization schemes, and hydrological models (e.g., Sheffield et al. 2014; Thiemig et al. 2013; Lemoalle et al. 2012; Todd et al. 2011) have shown some prospects as they have been widely employed to forecast and study the West African climatology and large-scale variability in the varied components of the hydrological cycle. Global hydrological models (GHMs) forced by global climate models and the latest greenhouse gases (GHG) concentration scenarios and atmospheric general circulation model (AGCM) have also shown potentials in global water assessment of droughts and water resources (e.g., Prudhomme et al. 2014; Schewe et al. 2013; Corzo Perez et al. 2011). However, the skills of these models (GHMs, Global Climate Models-GCMs, and Regional Climate Models-RCMs) are restricted due to (i) their poor representation of surface water balance (e.g., Alsdorf et al. 2007), (ii) bias and conceptual model uncertainties (e.g., Thiemig et al. 2013; Todd et al. 2011; Schuol and Abbaspour 2006; Lebel et al. 2000), (iii) dependence on computational estimates (e.g., Koster et al. 2004), (iv) lack of feedback processes involving anthropogenic impacts (e.g., Piao et al. 2010; Alsdorf and Lettenmaier 2003), and (v) model physics and choice of parameterizations (e.g., Oettli et al. 2011). Considerable progress is therefore required for the improved estimates of land-atmosphere impacts for GCM climate scenarios (Boone et al. 2009). But given the inherent problems of GCM in simulating primary aspects of the West African monsoon (e.g., Cook and Vizy 2006), and uncertainties in satellite estimates of some key hydrological fluxes globally (Lettenmaier 2005), then the implication of the problem is global.

\section{Framework for assessment of hydrological metrics}

The lack of a suitable framework to improve the characterization of space-time evolutions of hydrological quantities and extreme weather events limits climate forecasting systems, understanding of TWS dynamics, and the holistic assessment of key hydrological metrics (e.g., magnitude, frequency, duration, predictability, etc.). The impacts of climate variability and other processes of oceanic interannual variability (e.g., ENSO, Pacific Decadal Oscillation-PDO, etc.) in West Africa may result in contrasting outcomes on hydrological regimes. One of such example is the debate on rainfall recovery over West Africa. Nicholson (2005) and Lebel and Ali (2009) have contrasting cases of recovery possibly due to different reference periods. But essentially, they both show that while recovery was marked in some areas, rainfall deficit continued unabated in other Sahelian catchments. The failure of rainfall regime in one region does not translate to failure in other subregions (e.g., Ndehedehe et al. 2016c; Owusu and Waylen 2009), probably owing to different drivers of rainfall, local and land surface conditions. Assuming drought and wet conditions vary in space and time, then the existing methods (e.g., van Huijgevoort 2014; Panthou et al. 2014; Lebel and Ali 2009; Rouault and Richard 2003; Nicholson et al. 2000) used to analyze extreme weather events and hydrological conditions are insufficient, warranting further studies. It was elaborated further in a recent study (Ndehedehe et al. 2016c) that regional average time series of drought indices such as effective drought index (EDI), standardized precipitation index (SPI), groundwater drought index (GWI), and palmer drought severity index (PDSI) among several other indices (see, e.g., Li and Rodell 2015; Kasei et al. 2010; Ali and Lebel 2009; Laux 2009; Vicente-Serrano 2006; Heim 2002; McKee et al. 1993) hide the underlying spatial variability of the index and may lead to generalizations of wet and dry regimes. As the outcome of such drought indices is likely to be skewed, this may not be very helpful for predicting ecological responses, adequate evaluation of drought impacts, crafting of drought policies, and the fostering of campaign on regional adaptation 
strategies. Highlights from previous reports overwhelmingly agree that climate oscillations and tropospheric effects are associated with the characteristics of extreme weather events in the region. Hence, a spatiotemporal drought framework based on the localization of hydro-climatic signals could improve our knowledge of these climatic signals. The statistical decomposition of rainfall over West Africa, which indicates the Guinea Coast region is characterized by annual and bimodal rainfall signals (Fig. 2), illustrates the need for a spatiotemporal framework to enhance our understanding of hydrometeorological patterns. Relevant higher-order statistical techniques (e.g., independent component analysis) to support the regionalization of these signals are emerging innovative approaches in hydro-climatic studies ("Higherorder statistical tools and frameworks for spatiotemporal analysis of hydrometeorological data" section).

\section{Climate variability and drivers of land water storage}

\section{Impacts of rainfall on stream flow dynamics and surface hydrology}

In a study analyzing rainfall and extensive river flow records (1931-1990) in sub-Saharan Africa-SSA, Conway et al. (2009) found that in West Africa, rainfall variability is high and explained $40-60 \%$ and $60-80 \%$ of the changes in river flows during the periods of 1931-1960 and 1961-1990, respectively. Based on coefficient of variance, $\mathrm{Li}$ et al. (2005) showed that rainfall is a principal driver of water fluxes (river discharge and evapotranspiration) in West Africa and that hydrological variability is relatively higher in dry period than wet period. Conway et al. (2009) also confirmed this for SSA, but in addition indicated that river basin physiography and human interventions provide some form of control on interannual and interdecadal variability in river flows. In the Niger river basin, Tarhule et al. (2015) found that streamflow and rainfall fluctuate on cycles that are predominantly 2-4 years long. Further, the hydrological characteristics of three West African countries (Burkina Faso, Ivory Coast and Mali) during the 1951-1997 period showed that rainfall deficit was 15-20\%, while river flow deficit was $30-50 \%$ and more (Paturel et al. 2003). The regimes of most rivers are expected to be impacted by extreme climatic conditions, topography, soil characteristics, and perhaps vegetation layouts and morphology. Persistent drought conditions, for example, may lead to modifications in ecosystems that also contribute to the nonlinearity of rainfall-runoff transformation in the region (Paturel et al. 2003). The sudden and abrupt change point that occurred in 1969 in the rainfall and streamflow records in all sub-watersheds of the Niger Basin (Tarhule et al. 2015) due to droughts and long periods of reduced rainfall confirm that rainfall is a significant driver of stream flow in the region. However, several anthropogenic drivers such as the development of water infrastructures, land use change (especially deforestation), and expansion of agricultural areas in West Africa also play key roles in the alteration of river regimes (e.g., Ndehedehe et al. 2017a; Mahe et al. 2013; Paturel et al. 2003; Li et al. 2007). Moreover, several factors that influence runoff in West Africa were studied by Roudier et al. (2014). Apart from rainfall, they showed that potential evapotranspiration was also associated with runoff, in addition to water withdrawal, land use dynamics, and carbon effects, which they argue could also significantly have potential impacts on runoff changes. The surface water resources of West Africa are not only vulnerable to the impacts of climate variability but also to various forms of human activities. This has been demonstrated in some catchments of West Africa where outputs of numerical simulations suggested that deforestation increases annual stream flow by $35-65 \%$ ( $\mathrm{Li}$ et al. 2007). More studies related to the impacts of precipitation, surface water developments, and climate teleconnections as prominent drivers of West Africa 's surface hydrology are summarized in "GRACE hydrological applications in West Africa" section.

\section{Extreme hydro-climatic conditions}

\section{Droughts}

The highly variable climatic conditions in West Africa pose more threat to numerous water and ecological resources and make it considerably vulnerable to the impact of global climate change. For example, the spatial extent of Lake Chad, a prominent freshwater body in the world's largest interior drainage basin, declined from $24,000 \mathrm{~km}^{2}$ in the 1950 s to approximately $1700 \mathrm{~km}^{2}$ in recent times (see, e.g., Ndehedehe et al. 2016b; Wald 1990; Birkett 2000; Coe and Foley 2001; Leblanc et al. 2003; Lemoalle et al. 2012). This historic and dramatic decline of Lake Chad surface area (Fig. 3) is the aftermath of the persistent and long drought episodes of the 1960s and 1980s. These severe drought episodes were continental in nature and have been linked by some diagnostic studies (e.g., Bader and Latif 2011; Giannini et al. 2003; Fontaine and Bigot 1993; Janicot 1992) to large-scale climatological shifts and modifications in global SST.

In the Volta Basin, fluctuation in food production was attributed to high variability in rainfall distribution pattern (Kasei et al. 2010), while hydrological drought years were characterized with strong decline in the water levels of Lake Volta (see Ndehedehe et al. 2016c; Bekoe and Logah 2013). The long-term drying observed in the Central Equatorial Africa has been linked to SST variations and circulation changes associated with a weaker West African monsoon (Hua et al. 2016). Combining the long-term drying of 
the northern Congolese forest (Zhou et al. 2014) and the reported declines in GRACE-TWS in some parts of the Congo Basin (e.g., Ahmed et al. 2014; Crowley et al. 2006), hydrological conditions in the Congo Basin are therefore not favorable (e.g., Ndehedehe et al. 2018b) and could be a major constraint among other factors, to the proposed and ambitious water transfer from the basin to nourish the Lake Chad basin. It should be noted that despite the notorious impacts of climate variability on water resources, existing dossier on drought evolutions at both regional and basinspecific scales (e.g., Oloruntade et al. 2017; Ndehedehe et al. $2016 \mathrm{~b}, \mathrm{c}$ ) is insufficient and does not represent a satisfactory knowledge of hydrometeorological conditions in the region. Given that hydrological drought is said to be largely more driven by temperature than rainfall in the Niger south basin of Nigeria (Oloruntade et al. 2017), drought studies at smaller basin or country scales are important to reveal some latent and intrinsic climatic elements not visible in largescale studies. This has been demonstrated for the Volta, Lake Chad, and Congo Basins (see Ndehedehe et al. 2016b, c, 2019).

\section{Floods}

Whereas droughts, inter alia, contribute to food scarcity, famine, hydropower failure, and loss of biodiversity among others (e.g., Ferreira et al. 2018; Ndehedehe et al. 2016c, 2019; Zhou et al. 2014; Shiferaw et al. 2014; Bekoe and Logah 2013), excess water such as the most recent floods across the globe (USA, India, Bangladesh, Nepal, and Nigeria) could even be more devastating. For example, it was mentioned in Basu (2009) that the 2007 severe flood caused by a sequence of above-normal precipitation affected about 800,000 people in West Africa. A climatological diagnostics of this anomalous flood by Paeth et al. (2012) indicated that it was caused by La Niña event in the Pacific and a heightened activity of African easterly waves, among other factors. In 2009, torrential rains and floods affected an estimated 600,000 people in 16 West African countries, killing an estimated 159 people (Basu 2009).

Furthermore, severe floods ravaged West Africa in 2012 and 2013; destroying human lives, farmlands, properties; and causing outbreaks of cholera and other diseases (WMO 2013, 2015). The latest in the strings of multiple extreme wet events in the region is the recent mudslides and torrential flooding in Freetown, the capital city of Sierra Leone. According to several online reports, for example, the American Broadcasting Company (http://abcnews.go. com/International/wireStory/official-200-dead-sierra-leone -floods-49204542.), more than 400 people died in Sierra Leone, while at least 3000 people were rendered homeless as a result of this torrential flood and mudslides. Intense rainfall, deforestation, and other forms of human activities have been identified as immediate and preliminary factors for this deadly disaster (http://news.nationalgeographic. com/2017/08/sierra-leone-mudslide-deadly-video-spd/). As recently chronicled in West Africa (Ndehedehe et al. 2016b; Nka et al. 2015), wet conditions and flood phenomenon in some Sahelian catchments are becoming more frequent and severe. While the recovery of monsoon rainfall and the continued increase in the occurrence of extreme weather events will unavoidably trigger large changes in the region's TWS, more flood-related investigations are required to understand the vulnerability of the region to extreme wet conditions.

\section{Eco-hydrological processes}

\section{Ecosystem dynamics}

Studies of ecosystem dynamics in Africa are gradually emerging (e.g., Knauer et al. 2014; Hély et al. 2006) and show an increasing evidence of some level of disturbance. The decline of primary production, widespread desertification, and land degradation are, for example, well-known fallouts of unprecedented droughts and water deficit conditions in the region (e.g., Shiferaw et al. 2014; Bader and Latif 2011; Tucker et al. 1991). A recent study on Sahelian annual vegetation growth and phenology by Pierre et al. (2016) shows that drought shortened the mean vegetation cycle and reduced its amplitude. They argued further that despite the recovery of rainfall in the 1990s, the current conditions for green and dry vegetation are still below predrought conditions. It is mentioned in Lovett et al. (2005) that climate change will have major impacts on biodiversity with increased social consequences arising from ecological disturbance. This, as they have further highlighted, will have considerable implications on the continent's readiness to alleviate poverty and meet the Millennium Goals. Large segments of the West African region are heavily reliant on rainfed agriculture, making the impacts of climate variability on freshwater, vegetation dynamics, and weather conditions more deleterious and devastating in the region. As it turns out, economic development is hampered by strong hydrological variability caused by the impacts of climate variability in the region (e.g., Brown and Lall 2006). This may lead to critical water infrastructure which needs to help mitigate the impacts of hydrological variability on food production and livelihood.

\section{Hydrological indicators for surface vegetation dynamics}

Numerous studies in the past have used various remotely sensed precipitation and soil moisture products to investigate the water-driven variability of surface vegetation (see, e.g., Guan et al. 2014; Knauer et al. 2014; Chen et al. 2014; Seghieri et al. 2012; Huber et al. 2011; Do et al. 2005; Nicholson 
et al. 1990). Because of the complex combination of environmental, social, and multiple strings of anthropogenic factors in Africa, these products are somewhat restricted as drivers of vegetation dynamics. To this end, a new hydro-geodetic approach to understanding the water-driven variability of surface vegetation (the normalized difference vegetation index (NDVI) used as a vegetation proxy) using terrestrial water storage (TWS) inverted from Gravity Recovery and Climate Experiment (more details provided in "Gravity recovery and climate experiment" section) data is explored in this section. To examine the suitability of other hydrological indicators (e.g., GRACE-derived TWS) for the assessment of climate impacts on eco-hydrological processes, this section evaluates the NDVI-rainfall and NDVI-TWS relationships with focus on the Lake Chad basin. As illustrated in Fig. 4a, b, TWS is modestly associated with NDVI at the annual scale unlike rainfall, which indicated a somewhat weak association with NDVI. A considerably strong linear
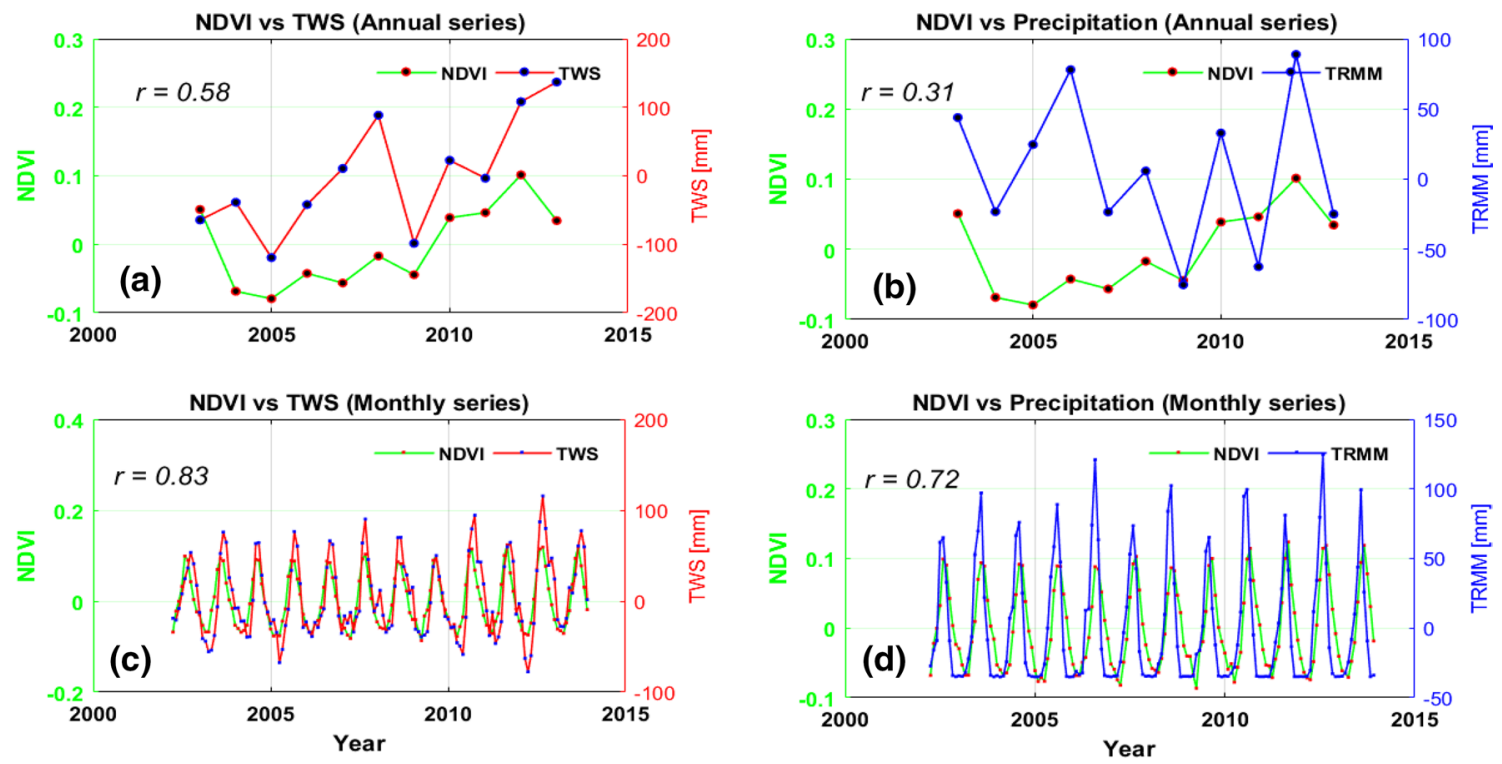

(e)
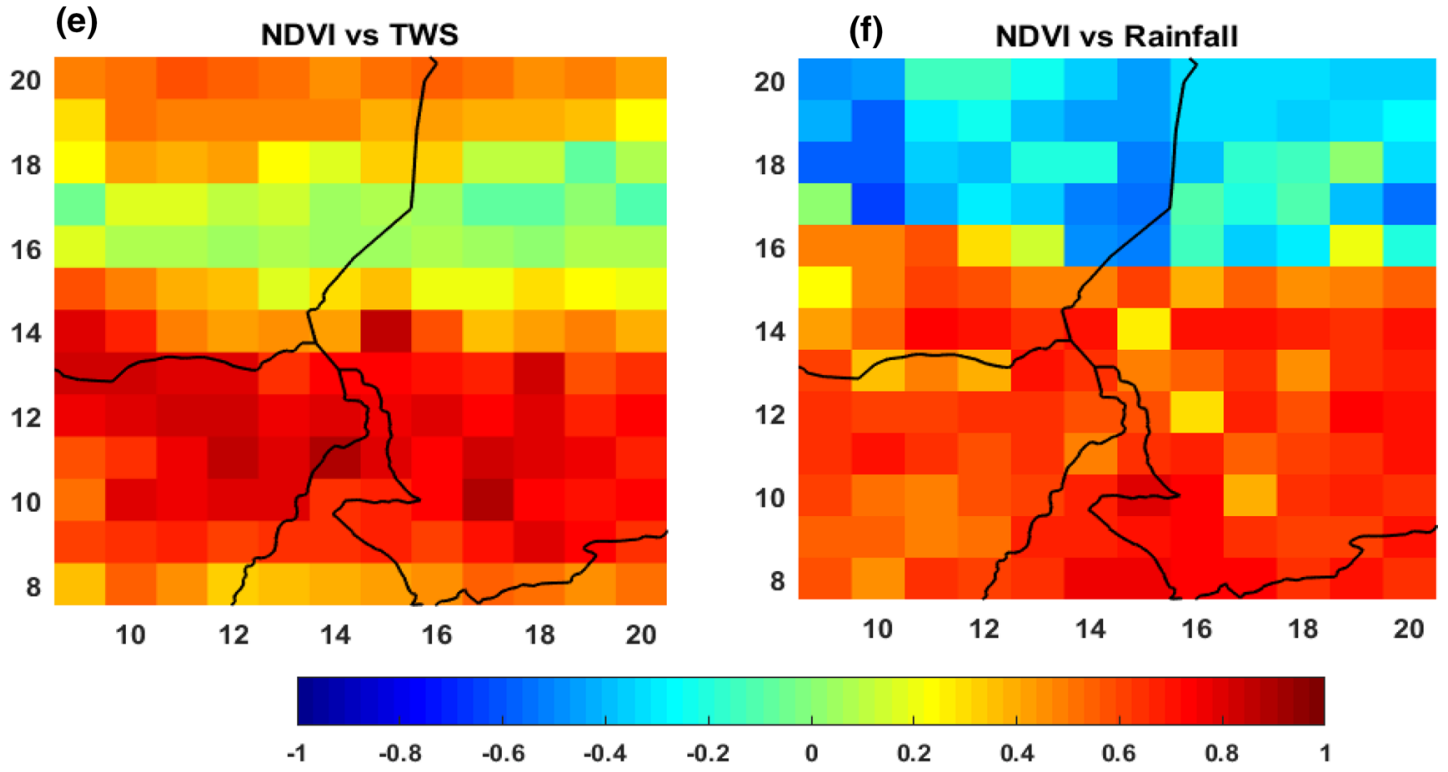

Fig. 4 Association of temporal series of NDVI with TWS and rainfall during the 2003-2013 period in Lake Chad basin-LCB (latitudes $8.25^{\circ} \mathrm{N}-20.25^{\circ} \mathrm{N}$ and longitudes $\left.9.75^{\circ} \mathrm{W}-20.25^{\circ} \mathrm{E}\right)$. a, b Correlations of annual departures of aerial averaged NDVI with TWS and tropical rainfall measuring mission (TRMM)-based precipitation. Before computing the annual departures, the annual data (NDVI, precipita- tion, and TWS) were aggregated from their corresponding monthly time series. c, d Correlations of monthly departures of NDVI with TWS and TRMM-based precipitation. e, f Spatial correlation coefficients of NDVI with TWS and rainfall, respectively, over the LCB using simple Pearson's correlation (N/B the scale bar indicates the range of correlation coefficients, i.e., -1 to +1 
correlation of monthly temporal series of NDVI with TWS $(r=0.83)$ and rainfall $(r=0.72)$ is largely indicative of the coupled effects of water availability on surface vegetation changes (Fig. 4c, d). Since changes in TWS components in the Sahelian countries are most likely to emanate from catchment stores (e.g., soil moisture, groundwater, etc.), the strong association of temporal series in NDVI with TWS would be expected. For semiarid ecosystems, the GRACE hydrological signals are changes in the terrestrial water column that includes both the saturated and unsaturated soil zones. Moisture changes in this unsaturated zone as mentioned in Yang et al. (2014) are relatively more sensitive to the impacts of climate variability. Consequently, GRACEderived TWS changes would mostly be observed moisture changes within the unsaturated zone where the root zone is located. Hence, the result in Fig. 4a-d presents TWS as a rather suitable hydrological indicator on the temporal variations of NDVI in the region. Other land surface processes associated with vegetation dynamics (e.g., evapotranspiration) and the soil characteristics of the region (e.g., Lopez et al. 2016) may contribute to TWS as a better predictor of vegetation dynamics compared to rainfall in the basin. The observed associations of NDVI with rainfall and TWS as indicated in Fig. 4a-d may be dynamic depending on the trajectory of human interference (i.e., in terms of land use change) in the ecosystem and climate change. Such relationship nonetheless provides new perspectives on the ecology of semiarid regions in Africa.

The grid-by-grid relationship of monthly NDVI with TWS and rainfall also indicates the strong potential of TWS and rainfall as hydrological controls in the region (Fig. 4e, f). Overall, TWS shows linear and a more consistent association with NDVI over the entire basin compared to rainfall. For example, TWS shows strong positive correlations with NDVI in the northern and southern catchments of the basin (Fig. 4e), while rainfall shows negative correlations with NDVI (Fig. 4f) in the northern catchment of the basin (rainfall also shows positive correlations with NDVI in the southern flank of the basin). The negative correlations of rainfall with NDVI in this northern catchment (Fig. 4f) suggest that NDVI still oscillates during long and protracted periods of limited rainfall. This perhaps can be caused by the physiological adaptations of Sahelian vegetation where root depth extends to the water table region (Huber et al. 2011; Seghieri et al. 2012). The only indicator of water availability would therefore be soil moisture and other components of catchments stores, which are all represented in TWS. Looking closely, correlations of NDVI with rainfall are predominantly 0.70 or less between latitudes $9^{\circ} \mathrm{N}$ and $13^{\circ} \mathrm{N}$ unlike the NDVI-TWS correlations that are mostly between 0.80 and 1.0 (Fig. 4e, f). NDVI correlations with TWS are, moreover, even stronger in the vicinity of the Lake Chad. The strong association of NDVI with TWS in some parts of southern Chad and northeast Nigeria could be due to changes mostly within the unsaturated soil zone. On the other hand, given that arid and semiarid regions are mostly groundwater-dependent ecosystems, this relationship may suggest complex water use mechanisms, possibly from groundwater (e.g., Guan et al. 2015). The development of such complex eco-hydrological interactions is more likely to emanate from the morphological and physiological adaptations of plants in arid regions that help them maximize water use. It is also critical to note that surface vegetation dynamics of some Sahelian ecosystems are not just driven by climatic factors as anthropogenic influence has been linked to observed changes in vegetation greenness (e.g., Herrmann et al. 2005). It is worthy of note that both at the annual and monthly timescales, TWS is a relatively better indicator of water availability compared to rainfall in LCB, suggesting that interannual variations in TWS can influence crop yield. In such arid regions where rain gauge data and hydrological information are considerably sparse and difficult to acquire, this could further articulate our understanding of the impacts of climate variability on agricultural production and food security.

\section{The role of human interventions on terrestrial hydrology}

Anthropogenic factors such as land use change and dam constructions have contributed to freshwater variability. For instance, the impacts of reservoirs and construction of dams along most of the world's major rivers have dramatically change the seasonal flow rates and trends in stream flow rates (e.g., Dai et al. 2009; Yang et al. 2004; Lammers et al. 2001). Human-induced changes in the ecosystem, accompanied by long-term rise in water tables and increase in recharge, were reported for southeast Australia and southwest USA (see Scanlon et al. 2005; Allison et al. 1990). In West Africa, despite the severe drought conditions of the 1970s and 1980s, extensive network of well observations revealed that groundwater resources and water table in Niger increased tremendously (Favreau et al. 2009; Leduc et al. 1997, 2001). This hydrological paradox, popularly known as the "Sahelian paradox," was attributed to a change in land clearing and changes in land use, which caused an increase in runoff (Descroix et al. 2009; Favreau et al. 2009; Séguis et al. 2004). Apparently, this phenomenon has also been observed in other Sahelian countries of West Africa (see, e.g., Gal et al. 2017; Mahé and Paturel 2009; Mahé and Olivry 1999) and new studies attempting to understand this hydrologically complex scenarios are emerging (e.g., Gal et al. 2017). Although Descroix et al. (2009), in addition, argued from a hydrological stand point that this observed anomaly could possibly emanate from the hydraulic conductivity of the soil and its infiltration capacity, Li et al. (2007) 
confirmed the impacts of land use change on the hydrological regimes of Niger and Lake Chad basins. They showed that complete deforestation increased simulated runoff ratio from 0.15 to 0.44 and annual stream flow by $35-65 \%$. The overwhelming litany of evidence from these considerable case studies may lead to the assumption this phenomenon is typical of the Sahel. But this appears not to be the case as a closer look at these Sahelian paradox studies indicate they were conducted at considerably small watershed scales (e.g., $500 \mathrm{~km}^{2}$ and $5000 \mathrm{~km}^{2}$ ). Other hydrological assumptions could lead to the conclusion that this is how the Sahel responds to the composite impacts of water deficit and land use change. A large-scale groundwater assessment from combined GRACE and model observation therefore could provide a broader perspective and perhaps more knowledge on this hydrological phenomenon and the hydrodynamics of the region. Such assessment can benefit from the multivariate methods discussed in "Higher-order statistical tools and frameworks for spatiotemporal analysis of hydrometeorological data" section.

Some recent contributions in the field of remote sensing hydrology to water resources development in West Africa have shown how deliberate human interventions can induce hydrological variability. For instance, Ndehedehe et al. (2017a) recently found that water ponding by the Akosombo Dam in the Lake Volta accounted for about $41 \%$ of the increasing trend in GRACE-TWS despite an apparent significant decline in precipitation between 2002 and 2014. The observed increased in TWS over the Volta Basin despite a significant fall in more than a decade precipitation during the same period (e.g., Ndehedehe et al. 2017a; Moore and Williams 2014; Ahmed et al. 2014) re-emphasizes the implications of human water management strategies on hydrology. The installations of hydraulic infrastructures in Senegal triggered rapid evolution of water resources as opposed to the 1980s when hydrological conditions were rather natural (Ngom et al. 2016).

The contraction of the Lake Chad's surface area was primarily caused by strong declines in regional precipitation patterns, restricting inflow from Chari-Logone river systems, which provide about $95 \%$ freshwater of the Lake. However, as indicated in several studies (see, e.g., Ndehedehe et al. 2016b; Birkett 2000; Coe and Foley 2001), water withdrawals from the Lake for irrigation purposes during water deficit periods compounded the effects of extreme droughts, resulting in about $90 \%$ decline of the Lake's surface area (Fig. 3). Apparently, this underscores the role of human activities in not only exacerbating the impacts of climate variability but also reshaping the stability of Lake's ecosystem. The human-modified droughts of the Lake Chad basin are typical of the Anthropocene, where various forms of human activities impact on catchment storage, soil properties, and hydrological processes, thereby modifying hydrological drought severity. Van Loon et al. (2016), for example, argued generally that urbanization impacts on recharge and infiltration rates, while soil moisture is influenced by deforestation, afforestation, desertification, and agricultural practices through evapotranspiration. In view of the aforementioned case studies, it can be reconciled that the combine effects of climate variations and human interventions, conjugated with the well-known strong land-atmosphere coupling in the region (e.g., Boone et al. 2009; Koster et al. 2004), will unarguably result in strong and profound influence on water resources systems and hydrological processes.

\section{Earth observations and model simulations in terrestrial hydrology}

Advances in remote sensing hydrology evidenced in new space-borne measurements in particular have made it possible to provide reliable estimates of precipitation, soil moisture, streamflow, lakes, soil moisture, glaciers and ice sheets, etc., from orbiting platforms (see, e.g., Petropoulos et al. 2015; Alsdorf et al. 2007; Lettenmaier 2005). Numerous studies (see, e.g., Agutu et al. 2017; Carrao et al. 2016; Funk et al. 2015; Dardel et al. 2014; Chen et al. 2014; Zhou et al. 2014; Du et al. 2013; Wagner et al. 2009; Sheffield et al. 2009; Tucker et al. 1991) have demonstrated the innate potentials of satellite data obtained from several remote sensing platforms such as optical, thermal, and microwave, in drought monitoring, land use change, regional water balance, and hydrological applications.

\section{Multi-resolution data in land surface hydrological studies}

Global reanalysis (e.g., Modern-Era Retrospective Analysis for Research and Applications-MERRA) and model data (e.g., WaterGap Global Hydrology Model-WGHM, CPC soil moisture, Global Land Data Assimilation SystemGLDAS, etc.) driven by observed meteorological forcing data have also been introduced in understanding global changes in climates and hydrological cycle (see, e.g., Döll et al. 2014; Rienecker et al. 2011; Rodell et al. 2004; Fan and Dool 2004; Dirmeyer et al. 2004). The WGHM model data provide estimates of groundwater recharge from surface water bodies in semiarid and arid regions (Döll et al. 2014), while global reanalysis such as the MERRA data provides atmospheric fields, water fluxes, and global estimates of soil moisture, which are very useful in land surface hydrological studies (Rienecker et al. 2011; Reichle et al. 2011). With the rapid upsurge in wireless and smartphone technologies; unmanned drones, aerial vehicles, and tethered balloons, scientists can now archive estimates of daily 
average rainfall, temperatures, floods; map snow depths; and monitor other critical hydrological quantities such as channel depth (McCabe et al. 2017). These sophisticated sensing platforms provide the remote sensing community and hydrologists with a plethora of opportunities to develop new frameworks that advance and facilitate our understanding of global changes in hydro-climatic conditions.

Be it satellite, model, or reanalysis data, their applications have enhanced and revolutionized our knowledge of hydrological cycle, water availability, and global change. For example, using a model soil moisture driven by a hybrid reanalysis-observation forcing dataset, Sheffield and Wood (2008) reported a small wetting trend in global soil moisture (1950-2000) that was attributed to increasing precipitation. Based on new data from the WaterGAP integrated global water resources model, Brauman et al. (2016) recently found periodic water shortage in $71 \%$ of world irrigated areas and $47 \%$ of large cities suggesting that water security depends largely on reducing society's vulnerability to water shortages. Multiple satellites and model data have been combined to produce a comprehensive indicator that provides balance for characterization while reflecting aspects of meteorological, agricultural, and hydrological drought information (e.g., Mishra et al. 2015; Niu et al. 2015; Du et al. 2013; Vicente-Serrano et al. 2012; Corzo Perez et al. 2011; Sheffield and Wood 2008). A new multivariate drought framework based on a fourth-order cumulant statistics (Ndehedehe et al. 2016c) also demonstrated the potentials of integrating multiple climate variables (in situ, model, and satellite data) in hydrological drought characterization, contributing to a broad framework of existing methods ("Higher-order statistical tools and frameworks for spatiotemporal analysis of hydrometeorological data" section). Even in a more recent study in East Africa (Agutu et al. 2017), a suite of remote sensing, land surface models, and reanalysis products showed strong potential for agricultural drought characterization, providing alternatives for the in situ data deficient region. Validated satellite precipitation (e.g., Tropical Rainfall Measuring Mission) and soil moisture products have been used to study meteorological processes and map surface soil moisture conditions in West Africa (e.g., Paeth et al. 2012; Pellarin et al. 2009; Nicholson et al. 2003). Net precipitation and other water budget quantities (e.g., rainfall, evapotranspiration, etc) estimated from Global Precipitation Climatology Center, ERA-interim, and GLDAS data over West Africa during the 1979-2010 period were analyzed recently by Andam-Akorful et al. (2017) using wavelet power transforms and coherence analysis. One significant aspect of the findings of the study is that observed decreasing rate of available freshwater (net precipitation) is highly coupled to a low-frequency modulating El Niño activity that induced lower changes in rainfall variance, as well as higher evaporation variance. Put together, these are some obvious indications of the opportunities that exist for large-scale hydro-climatic research that leverage on satellite programs and other multi-resolution data.

However, some of these datasets are problematic in West Africa as their skills in representing land surface and state variables (e.g., soil moisture) are restricted due to various human interventions, e.g., land use change, surface water developments (Ndehedehe et al. 2018b), and the factors mentioned earlier in "Limited observational networks" section. For this reason, hydrological research in West Africa may tend to benefit more from independent state-of-theart satellite observations, e.g., the Gravity Recovery and Climate Experiment. This is because the lack of sufficient in situ data for regional configurations and adequate initialization of outputs from hydrological models and reanalysis data for hydrological applications results in limited skills and poor representation of the West African land surface and hydrological state variables. Hence, the continued evaluation and validation of space-borne measurements and outputs from model simulations to assess regional water cycle should be given attention.

\section{Gravity recovery and climate experiment}

The Gravity Recovery and Climate Experiment (GRACE, Tapley et al. 2004) is a sophisticated time variable satellite gravity mission, comprising two identical satellites in nearcircular orbits with an altitude of $\sim 500 \mathrm{~km}$ and an inclination angle of $89.5^{\circ}$ that are separated by $\sim 220 \mathrm{~km}$ (Fig. 5). Unlike optical remote sensing platforms, which use visible, near-infrared, and short-wave infrared sensors to collect details of the earth surface, the two GRACE satellites use the satellite-to-satellite tracking system (Fig. 5). Each of the GRACE satellites is further equipped with a K-band microwave ranging system and high-precision accelerometers. Changes in the Earth's gravity field are caused mostly by dynamic processes that include mass redistribution of water (i.e., continental water storage, ocean, and atmosphere), gravitational tide in the solid Earth, post-glacial rebound, and variations in Antarctic and Greenland ice volumes (e.g., Swenson and Wahr 2002; Wahr et al. 1998). Accurate observations of these gravity fields are obtained from precise measurements of the distance between the two GRACE satellites as they orbit the Earth (see, e.g., Chen et al. 2005; Swenson and Wahr 2002; Wahr et al. 1998).

Since its inception, GRACE has given an unparalleled perspective to global terrestrial hydrology by providing quantitative estimates of monthly changes in TWS (soil moisture; groundwater; surface water-lakes, rivers, wetlands; snow; and canopy) over large spatial scales. Because of its spatial resolution $\left(200,000 \mathrm{~km}^{3}\right)$, the dynamics in multilayered land water storage (i.e., all aspects of TWS) can be measured at global or regional scales with an accuracy 
Fig. 5 Illustration of the Gravity Recovery And Climate Experiment (GRACE) satellite mission. The two identical twin satellites popularly known as Tom and Jerry are linked with intersatellite ranging system and equipped with global positioning system receivers and attitude sensors and high-precision accelerometers (Tapley et al. 2004). The ranging system is super-sensitive and can detect separation changes about one tenth the width of a human hair over a distance of $220 \mathrm{~km}$ (NASA 2002). The GRACE satellites are designed to map the global gravity field every thirty days. Image adapted from http:// spaceinfo.com.au/2010/07/23/ gravity-mission-down-under/

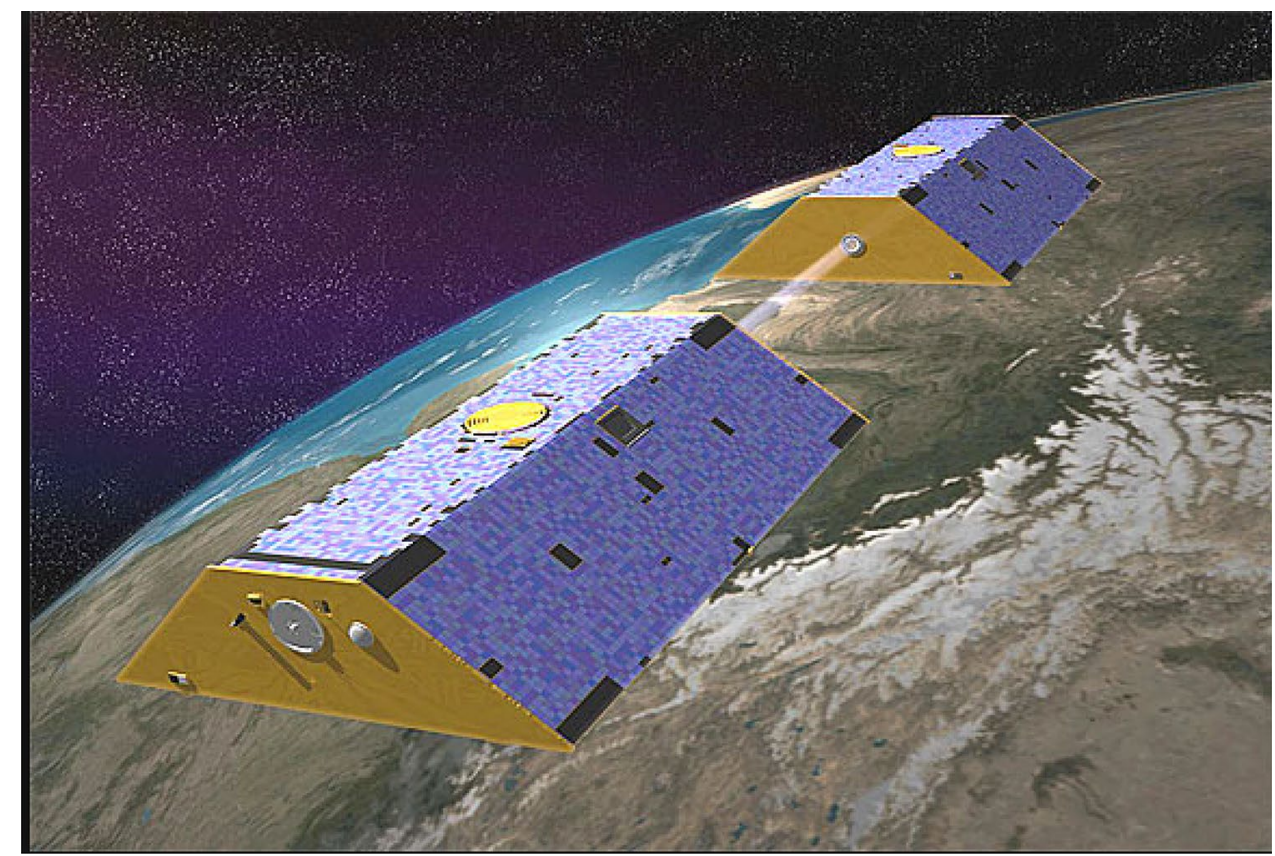

of $1.5 \mathrm{~cm}$ equivalent water height (Famiglietti and Rodell 2013). Apart from its broad applications in droughts, floods, terrestrial water budget, and ecosystem assessments (see, e.g., Zhang et al. 2016; Ndehedehe et al. 2016c; Thomas et al. 2014; Long et al. 2014; Reager et al. 2014; Yang et al. 2014; Long et al. 2013; Houborg et al. 2012; Chen et al. 2010), it is now one of the most vital tools in hydrological research, specifically in monitoring subsurface water storage, aquifer system processes, and evaluating groundwater resources (see, e.g., Castellazzi et al. 2016; Famiglietti et al. 2015; Alley and Konikow 2015; Famiglietti and Rodell 2013; Alsdorf et al. 2010; Henry et al. 2011; Tiwari et al. 2009; Swenson and Wahr 2007). The applications of GRACE data in hydrology research globally are growing and well documented (e.g., Humphrey et al. 2016; AndamAkorful et al. 2015; Senay et al. 2014; Sneeuw et al. 2014; Ndehedehe et al. 2018c; Wouters et al. 2014, and the references therein) and are only summarized here.

\section{GRACE hydrological applications in West Africa}

Early GRACE hydrological applications in Africa were mostly focused on other subregions (East, Central, and North Africa, e.g., Goncàlves et al. 2013; Awange et al. 2013a, b; Lee et al. 2011; Xie et al. 2012; Ramillien et al. 2008; Crowley et al. 2006). However, GRACE-based hydrological studies are gradually emerging in West Africa (see Ndehedehe et al. 2018a, c; Werth et al. 2017; Ndehedehe et al. 2016a, 2017b; Forootan et al. 2014; Lee et al. 2011; Henry et al. 2011). With the validation of GRACE data in the region (Nahmani et al. 2012; Grippa et al. 2011; Hinderer et al.
2009), more studies will be required to deploy GRACE observations in hydro-geological, groundwater, and climatological studies in the region. The utility of GRACE data for identifying long-term regional changes in groundwater storage in southern Mali and Niger basin has been reported (Werth et al. 2017; Henry et al. 2011). The outcomes in the Niger basin and southern Mali indicate opportunities for assessing groundwater dynamics in other major river basins in West Africa. The developments and evolutions of GRACE-derived TWS over West Africa as highlighted in previous reports ("Understanding space-time GRACE hydrological signals" section) suggest complex hydrological processes for the humid parts due to the presence of surface waters, wetlands, and a considerably strong interannual rainfall (see Ndehedehe et al. 2017a; Ferreira and Asiah 2015; Moore and Williams 2014; Ahmed et al. 2014). An array of novel findings and interesting insights in the aforementioned areas has been reported recently (see, e.g., Ndehedehe et al. 2016b, 2017a, b; Ferreira and Asiah 2015) and will advance essential aspects of research in remote sensing hydrology in the region.

\section{Some recent perspectives on drivers of land water storage dynamics}

The analysis of linear trends in yearly and monthly rainfall totals over West Africa (1980-2010) reveals that the Sahel rainfall has shown recovery marked by statistically significant increase in annual totals (Sanogo et al. 2015). The leading modes of standardized precipitation index over West Africa were also marked by above-normal rainfall 
(wet conditions) mostly between 1990 and 2014 over much of the Sahel (Ndehedehe et al. 2017b). These positive trends in rainfall coincide with some significant wetting patterns in observed long-term model derived land water storage over much of the Sahel (Ndehedehe et al. 2018b). Although the 2002-2006 period was somewhat dry in most regions of West Africa due to reduced precipitation, the extreme wet conditions of the 2006-2007 period caused by La Nina triggered anomalous increase in Lake Volta water levels and GRACE-derived TWS over most parts of West Africa (e.g., Ndehedehe et al. 2016a). Regardless of precipitation trends, GRACE-derived TWS has shown strong dominant patterns along the Guinea Coast countries of West Africa and significant increase over the entire region during the last decade (e.g., Ndehedehe et al. 2016a; Ahmed et al. 2014). These results align with a more recent GRACE study in the Niger basin, which reported an estimated linear rates of $93 \pm 61 \mathrm{~km}^{3}$ in groundwater stocks between 2003 and 2013 (Werth et al. 2017).
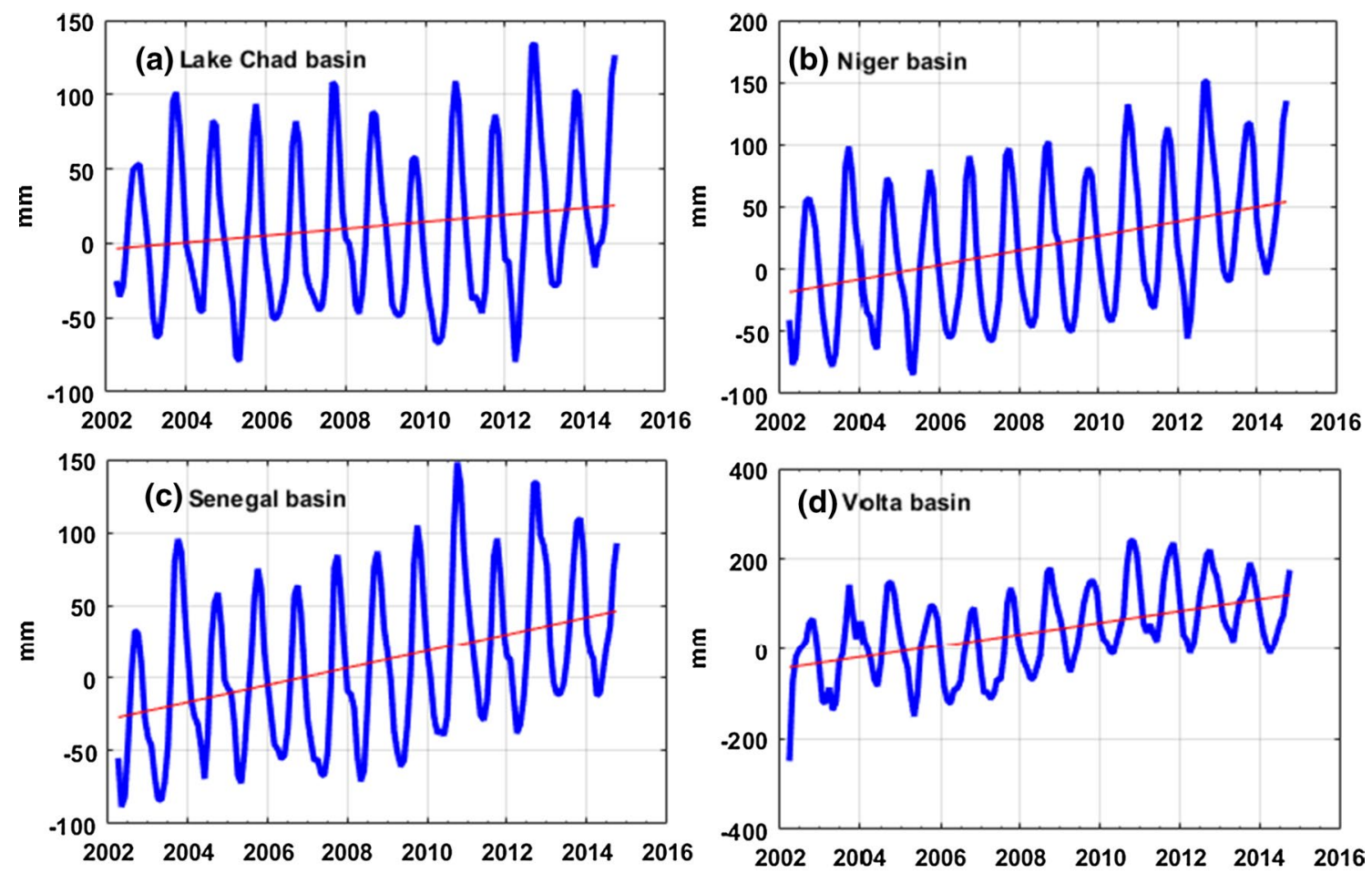

Year
As illustrated further in basin-specific studies (Fig. 6a-d), estimated trends in GRACE-derived TWS anomalies using the basin scale approach of Swenson and Wahr (2002) over Lake Chad ( $2.32 \pm 1.17 \mathrm{~mm} /$ year $)$, Niger $(5.81 \pm 1.19 \mathrm{~mm} /$ year $)$, Senegal $(5.22 \pm 1.02 \mathrm{~mm} /$ year $)$, and Volta ( $13.06 \pm 1.85 \mathrm{~mm} /$ year) basins indicate marked increase during the 2002-2014 period. The highest increase in TWS anomalies is observed over the Volta Basin due to strong gravimetric contributions caused by water ponding in the Akosombo Dam as highlighted in previous studies (see Ndehedehe et al. 2016a, 2017a; Moore and Williams 2014; Ahmed et al. 2014). In other basins nonetheless, these linear rates and trends (Fig. 6a-d) are largely perceived as a result of improved rainfall conditions over the same period. In light of the observed pseudo-rise and contributions of Lake Volta to TWS over the Volta Basin, which has been linked to water ponding by the Akosombo Dam (Moore and Williams 2014; Ahmed et al. 2014), understanding hydrological variability of the basin became challenging. For instance, although precipitation, discharge from the Volta river system and net

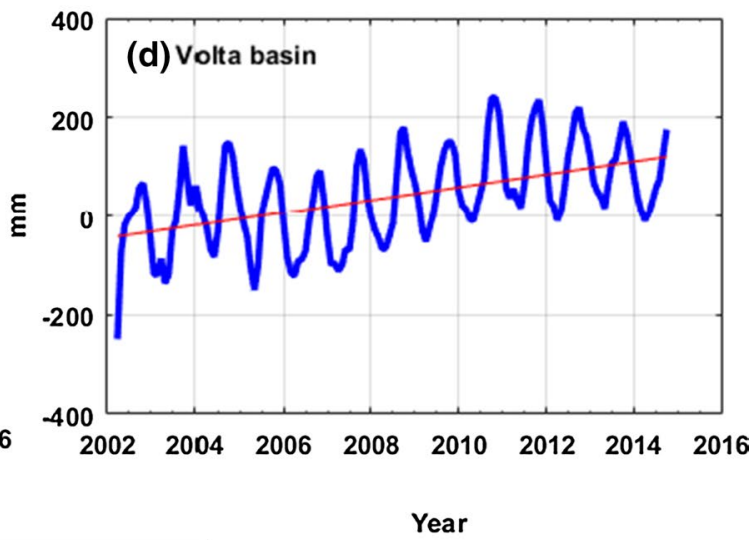

Fig. 6 Trends in GRACE-TWS anomalies over major river basins in West Africa for the period between 2002 and 2014. Trends in TWSA over a Lake Chad, b Niger, c Senegal, and d Volta Basins were estimated using the basin scale approach described in Swenson and Wahr (2002). The GRACE (Tapley et al. 2004) satellite mission provides changes in TWS (sum total of changes in groundwater, soil moisture,

surface waters, and canopy) based on observations of the Earth's time variable gravity fields (e.g., Ndehedehe et al. 2016a; Wouters et al. 2014). The GRACE Release-05 (RL05) spherical harmonic coefficients from the center for space research (CSR), truncated at degree 60, covering the period 2002-2014 were used to estimate TWS over these basins 
precipitation reduced significantly over a 10 -year period that coincided with the GRACE period, TWS over the Volta Basin showed significant and considerable rise during the same period (see Ndehedehe et al. 2017a). By exploring a novel approach based on a two-step procedure that incorporates a weighted least squares formulation of global spherical harmonic analysis and cumulant statistics, a further step was undertaken by Ndehedehe et al. (2017a) recently, to quantify the contribution of Lake Volta to observed trend in GRACE-derived TWS over the Volta Basin (2002-2014). They showed that the observed decline in GRACE-derived TWS (i.e., after removing the strong gravimetric changes of the Lake Volta) was consistent with more than a decade decline in precipitation within the vicinity of the lower Volta Basin where the lake is located. This decline in precipitation over the Volta Basin also coincided with significant reduction in stream flows of the Volta river system and net precipitation. It is here noted that large surface water development schemes such as the Lake Volta will have direct implications in water budget assessment. Hence, the combined impacts of anthropogenic, climatic, and natural drivers (e.g., natural climate variability) are challenging issues that require an integration of science and policy in water resources planning in the basin.

Whereas rainfall at interannual and seasonal timescales drives TWS in West Africa (Ndehedehe et al. 2016a), drivers of hydrological variability are somewhat unclear in the Congo Basin (i.e., much of Equatorial Africa). The drying trends observed in the northern Congolese forest were found to be generally consistent with declines in rainfall, TWS, and aboveground woody and leaf biomass (Zhou et al. 2014). But observed declines in TWS in three sub-basins (Congo, Ubangi, and Sangha) of the Congo river basin during the 2003-2012 period were attributed to deforestation (Ahmed et al. 2014). Pioneer GRACE results over the Congo Basin showed that it lost about $280 \mathrm{~km}^{3}$ of water between April 2002 and May 2006 largely caused by a loss in runoff and evapotranspiration (Crowley et al. 2006). One may therefore argue that the hydrological conditions of the Congo Basin and much of Central Africa are somewhat complex. Apart from non-climatic drivers, the local influence of sea surface temperature (SST), atmospheric circulation features, and mesoscale convective systems, which regulate rainfall through their control on the rain belt, have also been reported (e.g., Farnsworth et al. 2011; Balas et al. 2007). The Congo Basin is an epic biodiversity that houses the world's second largest rainforest. As highlighted by Washington et al. (2013), the basin is among the three prominent convective regions on Earth that dominates global rainfall climatology during transition seasons. Its hydrological characteristics, nonetheless, are less reported compared to the Amazon basin where a relatively large inventory of hydrology-related studies exists (Alsdorf et al. 2016). Hence, more studies will be required to build a concrete contemporary understanding of hydrological processes, climate feedbacks, and interactions in the region's biophysical systems.

\section{The influence of global climate on terrestrial water storage}

Considerable case studies in the past have investigated the impacts of perturbations of the nearby oceans, quasi-periodic phenomena (e.g., ENSO), and other low-frequency climate oscillations on precipitation changes in Africa. While such impacts have been widely reported and less debated, the role of global climate on long-term terrestrial water storage (TWS) has not been studied. Only recently was the influence of three prominent climate teleconnection indices (ENSO, AMO, and IOD) on GRACE-derived TWS and global reanalysis data documented over West Africa by Ndehedehe et al. (2017b). The study revealed that ENSO and other low-frequency climate oscillations of the Atlantic Ocean (AMO) are important drivers of long-term variations in TWS, affecting its distributions and temporal changes. Prior to this, some pioneering studies (see Phillips et al. 2012; Boening et al. 2012) drew the attention of the hydrological community to the impacts of ENSO on global mean sea level and continental water storage. In other reports (e.g., Sheffield and Wood 2008), variations in global soil moisture have been associated with variabilities in ENSO, though AMO supposedly impacts soil moisture variations in other regions including West Africa. Interestingly, ENSO, AMO, and PDO among other climate modes play key roles in the characteristics of extreme climatic conditions in West Africa (e.g., Ndehedehe et al. 2016b, c; Paeth et al. 2012).

Furthermore, new results re-emphasizing and validating the influence of ENSO on variations in TWS are emerging (e.g., Ni et al. 2017). The study by Ndehedehe et al. (2018b) found ENSO-related equatorial Pacific SST fluctuations as a major teleconnection with considerable significant association with long-term TWS reanalysis data over large portions of sub-Saharan Africa. ENSO is arguably one of the leading modes of oceanic variability that explains variability in TWS as the aforementioned studies suggest. However, for West Africa, there are other climate oscillations of the Atlantic SST that are also important drivers of long-term variations in TWS. The observed presence of AMO-driven TWS in much of the Sahel and Guinea Coast regions and the modest association between variabilities in Atlantic Meridional Mode and TWS over West Africa suggest the important role of Atlantic SST variability in the region (Ndehedehe et al. 2017b, 2018b). Away from these large-scale climate teleconnection impacts, Hoff (2009) identified some biophysical, socioeconomic, and institutional teleconnections that exist within global water systems. These teleconnections whose characteristics have been detailed in the aforementioned synopsis, link causes, and effects on water resources 
remotely and may lead to serious disturbance and perhaps a breakdown of water-dependent socio-ecological systems. As anthropogenic factors also play key roles in the dynamics of global water systems ("Earth observations and model simulations in terrestrial hydrology" section), water management decisions will have to embrace dynamic policy solutions and meaningful decisions that integrate both climate and human factors.

\section{The future of satellite geodetic missions in hydrology}

Apart from the growing applications of GRACE observations in hydrology and Earth science, other sustained investments in satellite geodetic programs have provided large coverage of dynamics in terrestrial water bodies. For example, measurements obtained from interferometric synthetic aperture radar (InSAR), radar altimetry (TOPEX/Poseidon), ERS satellites, Envisat and Jason1 missions, Ice, Cloud and land elevation satellite (ICESat), Shuttle Radar Topography Mission (SRTM), Global Positioning System (GPS), Japan's Advance Land Observing Satellite (ALOS), among others, have proved to be useful in understanding the impacts of climate variability on the temporal and spatial dynamics of surface water resources (e.g., Tourian et al. 2017; Ndehedehe et al. 2017a; Lee et al. 2014; Alsdorf et al. 2001, 2003, 2007; Frappart et al. 2006; Lettenmaier 2005; Birkett 1995, 2000). All of these satellite programs and global land surface schemes have ignited a plethora of scientific findings that are not only informative but also useful for public policy and management decisions related to water resources (e.g., Ndehedehe 2017). Currently now streaming is the use of InSAR data not just for detecting land subsidence but assessing groundwater abstraction-induced drought (e.g., Castellazzi et al. 2016). Some other novel application areas would be to integrate GRACE observations with InSAR to monitor human-induced changes in groundwater aquifers and predict the likelihood of surface displacements in areas with long history of mining operations and groundwater use. Moreover, such independent observations would be essential in the Sahel of West Africa to address the widely reported hydrological paradox of increasing groundwater stocks during drought periods.

The previous GRACE mission came to an end in December 2017 after more than 15 years of gravity observations across the globe. It was replaced by the launch of a new-generation time variable gravity satellite pair, the GRACE Follow-On (GRACE-FO) mission in May 22, 2018. In non-industrialized regions where hydrological infrastructures and observational networks are in decline, non-operational or sparse (e.g., Alsdorf et al. 2003; Alsdorf and Lettenmaier 2003), the GRACEFO mission would be the only operational, state-of-the-art, and most sophisticated gravity mission that would benefit hydrological and climate research. The anticipated finer spatial resolution of GRACE-FO mission would allow not just the quantification of the terrestrial water budget components but the closure of water balance with limited uncertainties. The new spatial resolution would be the aftermath of an optimized system design and the inclusion of an experimental laser ranging system to complement the $\mathrm{K}$-band microwave ranging system in the previous GRACE mission.

Another future space agency mission currently under development and scheduled to be launched by 2020 as published by National Aeronautics and Space Administration (NASA, www.jpl.nasa.gov/missions/surface-water-and-ocean-topog raphy-swot) is the Surface Water and Ocean Topography (SWOT) mission. The SWOT mission is expected to provide detailed measurements of surface water storage variations (i.e., wetlands, lakes, or reservoirs), complementing the GRACE mission. As indicated in the SWOT mission document (https:// swot.jpl.nasa.gov/files/swot/SWOT_MSD_1202012.pdf), the scientific rationale for the development of SWOT is twofold. Firstly, to make high-resolution, wide-swath altimetric measurement of the ocean surface topography that will advance the understanding of the oceanic mesoscale and sub-mesoscale processes. Secondly, the quest for a mission that will measure the elevation of water on land that will boost fundamental advances in the knowledge of the spatiotemporal distribution of the storage and discharge of terrestrial water. Nevertheless, some other space agency missions relevant to hydrology have also been flagged for deployment in the coming years. They include Water Cycle Observation Mission (WCOM) and NASA's ICESat-2 (Ice, Cloud, and land Elevation Satellite). WCOM is expected to be launched by 2020 and is designed to measure snow water equivalent, soil moisture, precipitation, atmospheric water vapor, and other state variables, while ICESat-2 is primarily designed to map ice sheet, and in addition monitor surface water elevations (e.g., McCabe et al. 2017). ICESat-2 is the second generation of the laser altimeter ICESat mission and is optimized to use a micro-pulse multi-beam approach. It is scheduled for launch by 2018 to determine ice sheet mass balance as well as cloud property information, provide topography and vegetation data around the globe, plus the polar-specific coverage over the Greenland and Antarctic ice sheets (see https://icesat.gsfc.nasa.gov/).

\section{Higher-order statistical tools and frameworks for spatiotemporal analysis of hydrometeorological data}

The plenitude of several available climate, hydrological, or gravimetric data, be it in the form of satellite observations, reanalysis, or model-generated products, has enhanced the continuous monitoring of land surface conditions, 
biodiversity, weather, and natural systems. During the last decade, these data have been considerably employed across the globe to study various forms of droughts (meteorological, agricultural, and hydrological), floods, ecological processes, and in the characterization of critical hydrological metrics, among others (see, e.g., Agutu et al. 2017; Ndehedehe et al. 2016c; Van Loon et al. 2016; Velicogna et al. 2015; Sheffield et al. 2014; Zhou et al. 2014; Thomas et al. 2014; Long et al. 2014; Reager et al. 2014; Yang et al. 2014; Vicente-Serrano et al. 2012; Sheffield and Wood 2008; Koster et al. 2004). However, the need to understand and localize the multiple and growing climate signals is now in the forefront of climate science. This interest in regionalising hydro-climatic signals at various time and geographic (e.g., global and regional) scales is increasing and has resulted in several applications of multivariate techniques such as principal component analysis (e.g., Preisendorfer 1988) in the decomposition of climate data, geophysical signal separation, and drought analysis (e.g., Ndehedehe et al. 2016a; Kurnik et al. 2015; Sanogo et al. 2015; Ivits et al. 2014; Nicholson 2014; Santos et al. 2010; Bonaccorso et al. 2003; Semazzi et al. 1988). Other approaches to drought variability and or forecasting however, along with improving general circulation model (GCM) predicted rainfall, have been studied (though less reported) using wavelets analysis, canonical correlation analysis, among others (e.g., Mehr et al. 2014; Okonkwo 2014; Kumar et al. 2013; Singh et al. 2012; White et al. 2004).

\section{Understanding space-time GRACE hydrological signals}

Following some of the poor skills of global hydrological models (e.g., Ndehedehe et al. 2018b), advocating for the improved representation of the African land surface and hydrological state variables (e.g., soil moisture) in these models and reanalysis data has been the basis of some emerging regional studies (e.g., Agutu et al. 2017). Whereas this can be considered a logical step that could promote hydrological research, more validation studies would be essential to further assess the uncertainties in these data, establishing their limits of reliability and use in the region. For example, the MERRA reanalysis and WaterGap model cannot reproduce the temporal variability as captured by GRACE-TWS owing to their limited skills in the Congo Basin unlike the Sahel and some Guinea Coast zones (Figs. 7a and 1a). (a)

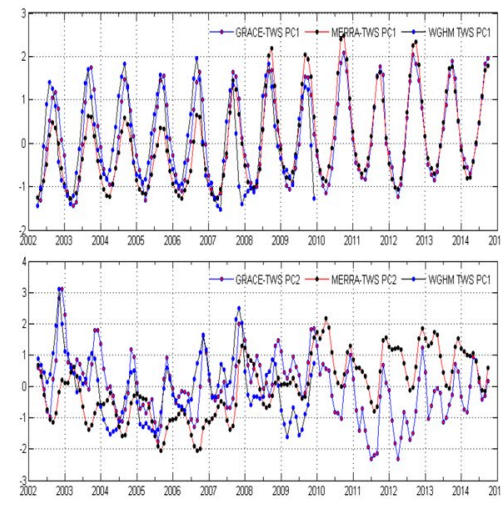

GRACE.TWS BOF1: $35 \%$

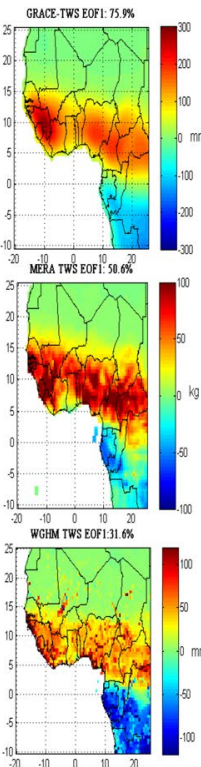

(b)

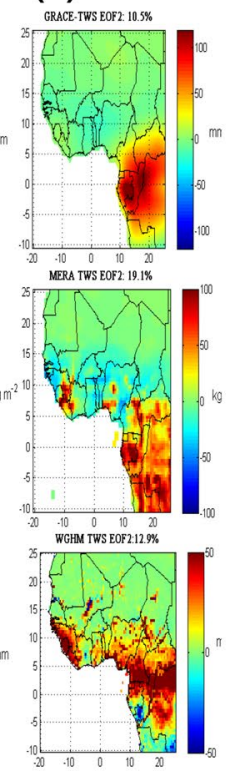

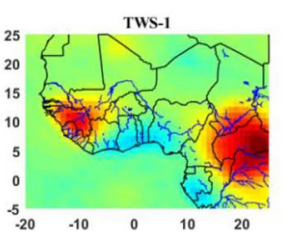

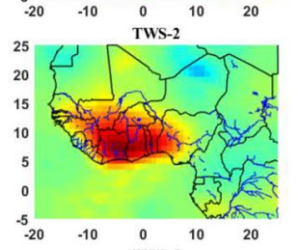

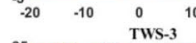

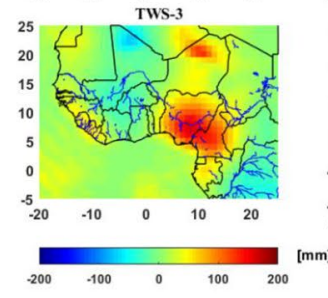

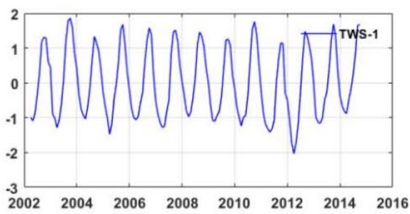
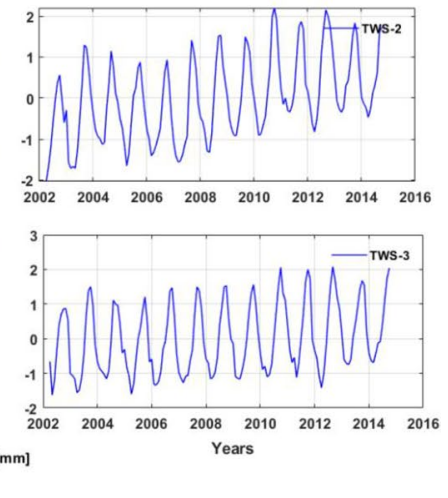

Fig. 7 Illustrating multivariate analyses of land water storage obtained from time-variable gravity observations, reanalyses data, and outputs from hydrological models. a Comparing the spatiotemporal patterns of MERRA (2002-2014) and WGHM-based TWS (2002-2009) products over West Africa with GRACE-derived TWS (2002-2014) based on PCA. The EOFs (right) and the corresponding temporal patterns or PCs (left) are constructed similar to Fig. 2. The spatiotemporal patterns of GRACE-TWS here include Central African countries and much of the Congo Basin area (tropical West
Africa-TWA). This map is fully adapted from Ndehedehe et al. (2018b) with permission granted on the November 27, 2018. b The space-time patterns of GRACE-derived TWS over TWA using cumulant statistics (e.g., Ndehedehe et al. 2016b; Cardoso and Souloumiac 1993). The independent components (ICs) and spatial patterns are constructed similar to Fig. 8. The blue lines on the spatial patterns corresponding to the ICs are water bodies (rivers, lakes, and reservoirs) 
However, in addition to collaborating with local institutions for the provision of existing ground observations for parameterizations and validation purposes, the strong land-atmosphere interaction and the highly variable hydrological conditions should be understood to make necessary adjustments in hydrological models. Understanding this variability and its various drivers has been the basis of some of the author's pioneering works in the region (e.g., Ndehedehe et al. 2016a, 2018b, c; Andam-Akorful et al. 2017). As the PCA method indicates (Fig. 7a), the two dominant modes of land water storage variability are found at the Guinea Coast/ Sahel regions and the Congo Basin area and are consistent with rainfall evolutions (Fig. 2). While the first mode of GRACE-TWS was largely precipitation driven, the strong dynamics of the Congo River accounted for more of the observed variability in GRACE hydrological signals (Ndehedehe et al. 2018b). A further assessment of independent patterns of TWS using cumulant decomposition techniques is illustrated in Fig. 7b. The regionalization of TWS using this technique has been very useful to understanding the evolutionary behavior of TWS in specific locations. As can be seen over the Volta Basin area (TWS-2, Fig. 7b and cf. Fig. 1), the rising trend in the time series associated with the spatial pattern is caused by water ponding of the Akosombo Dam in Ghana, contrary to other regions where temporal patterns are largely influenced by the annual rainfall patterns (TWS-1 and TWS-3, Fig. 7b). Statistical decomposition methods are helpful in identifying climatic drivers such as global teleconnections or other prominent hydrological signals, e.g., variability in groundwater for semiarid regions of the world with massive groundwater abstraction. Space-time evolutions of state variables are essential for improved understanding of variability. The application of these statistical methods on GRACE-derived TWS could become the most efficient approach to quantify and assess the interplay among notable drivers, which include climate change, natural, and human-induced changes that contribute to variations in freshwater stocks. For example, this was demonstrated by Ndehedehe et al. (2018b) who applied PCA to regularized TWS and sea surface temperature anomalies and subsequently used the canonical scheme (canonical correlation analysis) to assess the coupled variability of dynamics in land water storage with SST anomalies. Furthermore, multivariate techniques are also very handy in isolating specific hydrological signals like those emanating from major lakes with strong gravimetric variations (e.g., Ndehedehe et al. 2017a).

\section{Drought characterization and regionalization}

To improve the regionalization of drought signals at different aggregation scales, a fourth-order cumulant statistics, the independent component analysis (e.g., Cardoso and Souloumiac 1993; Cardoso 1991) was recently introduced in region-specific case studies (see Ndehedehe et al. $2016 \mathrm{~b}, \mathrm{c})$. This cumulant-based approach to the analysis of extreme hydro-climatic conditions has shown great skills in studying space-time developments of droughts compared to previous approaches (e.g., principal component analysis) of regionalizations and can be applied in other regions of the world. Theoretical and mathematical details of cumulant statistics and its applications have been documented, and interested readers can see relevant studies (e.g., Cardoso 1999; Cardoso and Souloumiac 1993; Cardoso 1991; Ndehedehe et al. 2016b, c). As illustrated in Fig. 8, the leading modes of standardized precipitation index (SPI) over West Africa are spatially distinct and in general create a dichotomy of extreme weather events between the semiarid Sahel and the humid coastal areas of West Africa. Drought amplitude and its variability in the region are unique depending on rainfall conditions and perhaps other climatic and human drivers. The notorious droughts of the early 1980s, for example, persisted in the Sahel at the 12-month aggregation scale compared to other regions of West Africa, though the tendency toward wet conditions has increased (with marked fluctuations). Such tendencies are due to recovery of rainfall in the 1990s and improved rainfall conditions during the last decade (Fig. 8). SPI temporal series aggregated at 12-month scale are representative of hydrological droughts (e.g., Ndehedehe et al. 2016b, c; Li and Rodell 2015; Vicente-Serrano 2006; Rouault and Richard 2003; Hayes et al. 1999). Hydrological droughts are usually periods characterized by prolonged deficits in rainfall. This often leads to reduced alimentation, desiccation, and depletion of lakes, reservoirs, stream flows, and, eventually, a decline in groundwater levels, depending on human response to water deficit conditions. This was the case in Lake Chad when protracted periods of hydrological droughts, accompanied with excess water withdrawals from the lake for agricultural purposes, resulted in a humongous contraction of its surface area (Fig. 3). Further, in Fig. 8, this multivariate technique clearly marks out the hydrological drought condition of the Congo Basin between 2003 and 2007 before it experienced the La Nina upsurge later in 2007. It further shows that temporal evolutions of SPI over the Sahel are well associated with AMO unlike the SPI temporal patterns of other regions (Ndehedehe et al. 2017b). This approach supports location-specific assessment of large-scale impacts on extreme climatic conditions. Arguably, this could help reduce the polarizations surrounding the debates on extreme rainfall conditions and the roles of climate modes that induce it variability. This new multivariate technique in spatiotemporal drought analysis is more comprehensive and robust and contributes to a large framework for drought assessment that will complement existing methods. 

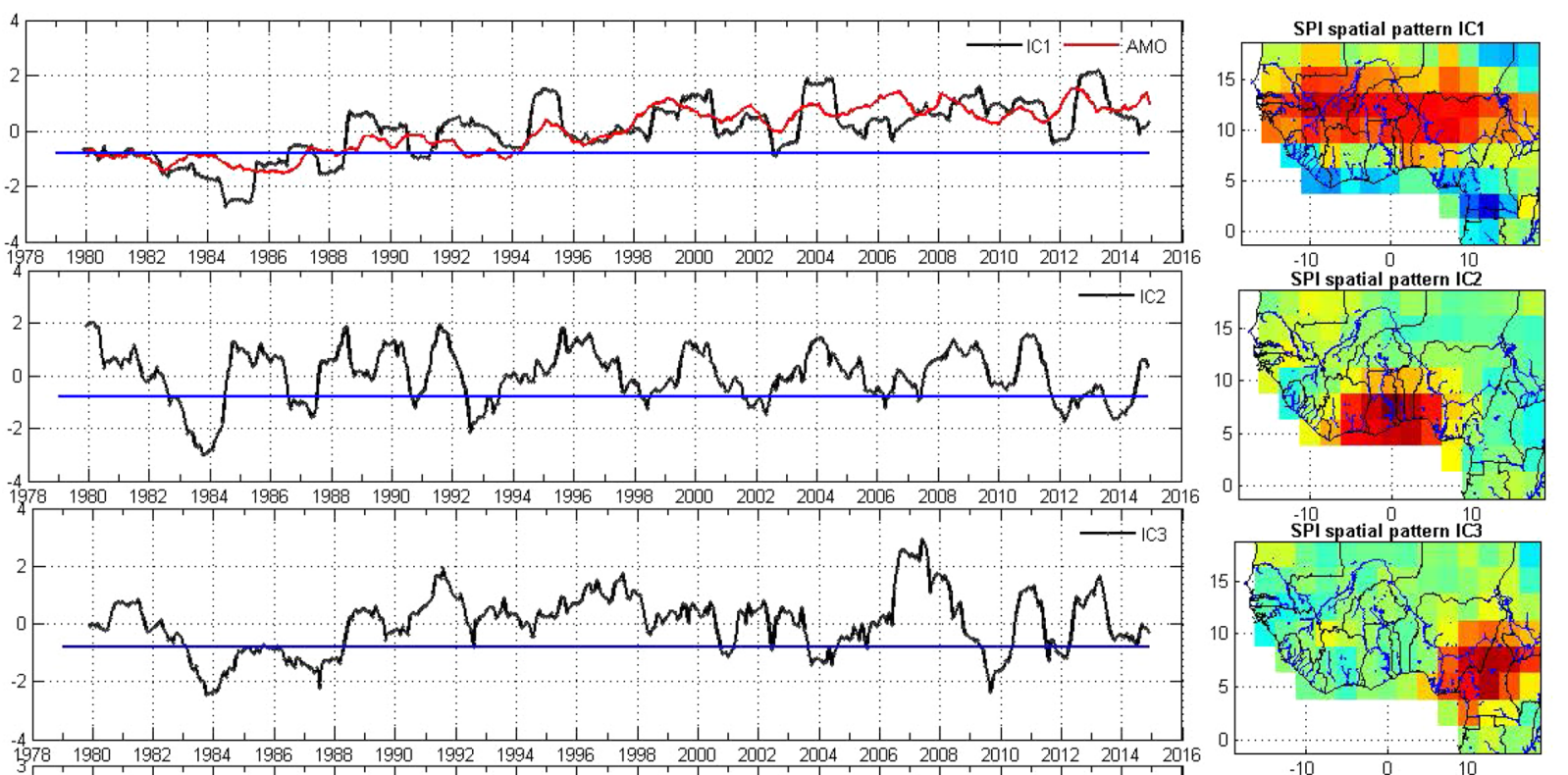

SPI spatial pattern IC
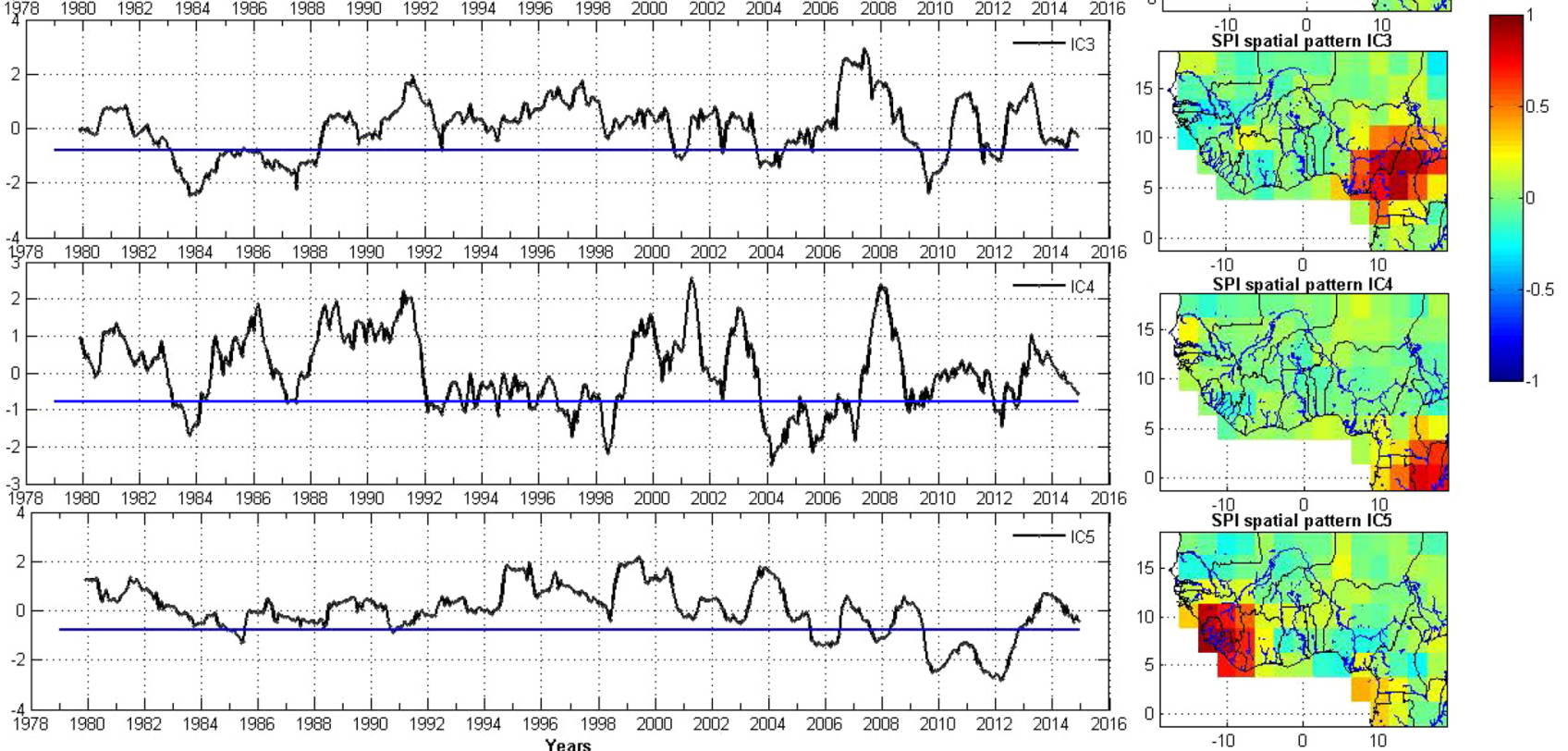

Fig. 8 Illustration of the spatiotemporal SPI (standardized precipitation index) patterns over different hydrological zones of West Africa using 12-months gridded SPI values (adapted from Ndehedehe et al. 2017b). The localized SPI values are based on McKee et al. (1993) description and are computed using GPCP-based precipitation product for the period 1979-2014 (SPI values are in standardized units). The localization of SPI was achieved by rotating significant orthogonal modes of 12-months SPI values using cumulant statistics (e.g., Ndehedehe et al. 2016b; Cardoso and Souloumiac 1993). SPI values for drought classification and characterization are jointly derived and

\section{Conclusion}

The deleterious impacts of unmitigated climate change in West Africa represent significant and considerable negative impacts on agriculture, hydropower, economic development and result in ripple effects on the socioeconomic systems of the region. As most agricultural goods are produced in regions that are vulnerable to water-related impacts, this will have massive implications not just on the economy of West Africa but other regions of the world that indirectly consume the water resources of West Africa. Despite this strategic importance of West African interpreted together using the temporal evolutions of SPI (left) and their corresponding spatial patterns (right). AMO is associated with the characteristics of SPI over the Sahel region. Blue lines on the SPI spatial patterns are hydrological units (rivers, lakes, and other water bodies), while those on the temporal series are drought thresholds. SPI signals and soil moisture index have also been localized in basinspecific studies over West Africa, where ENSO and several low-frequency climate oscillations such as the PDO, Arctic Oscillation, and North Atlantic Oscillation were associated with drought characteristics (see Ndehedehe et al. 2016c)

countries to the global community, there are still considerable and prominent gaps, however, in the knowledge of how global changes in climate impact on the region's water resources systems. Not only is hydrology poorly understood, large-scale temporal and spatial dynamics in TWS, and a framework to characterize key hydrological metrics and extreme weather events are lacking in West Africa. As this review indicates, an increasing number of constraints, e.g., lack of robust investments in gauge measurements for meteorological and hydrological applications among other factors, combine to restrict the availability of in-situ observations for hydro-climatic research 
that addresses the aforementioned issues. Advancements in space agency programs and sophisticated sensing platforms undoubtedly have revolutionized terrestrial hydrology research around the world. However, as opposed to other hydrological regions of the world (e.g., the Amazon basin) with considerable reports on hydrological processes, similar studies over West Africa are conspicuously limited in the volumes of existing studies and catalog of hydrological journals.

Understanding the impacts of global climate on regional changes in terrestrial water system is warranted for few reasons: it will (i) support policy and risk management strategies, (ii) promote the need for management and sustainability of water resources, (iii) foster campaign on regional adaptation strategies in the event of extreme hydrological conditions, (iv) advance hydro-climate research in terms of optimizing climate and hydrological models, and (v) provide new perspectives on eco-hydrological processes in West Africa. As this manuscript illustrates, opportunities for hydro-climatic research in West Africa that leverage on sustained investments in satellite geodetic programs exist. The potentials of satellite gravity observations, gauge and high spatial resolution satellite precipitation data in the region, are some opportunities to further assess the representation of the land surface and atmospheric states in global reanalysis models.

The highlights in this manuscript indicate that these geodetic programs (e.g., GRACE and radar altimetry missions), along with other remote sensing satellite missions, and auxiliary data synthesized by forcing global land surface models with historical meteorological data (reanalysis) have only within the last two decades ignited a plethora of scientific findings. These outcomes are not only informative but could be considerably useful for public policy and management decisions related to water resources. Given the poor density of groundwater bores and other observations, hydrological research in West Africa is expected to benefit immensely from independent space geodetic programs such as the GRACE mission. Limited skills in model outputs and poor representation of the West African land surface in reanalysis data are few notable constraints to large-scale terrestrial hydrology-focused investigation in West Africa. Therefore, to improve our contemporary understanding of West Africa's terrestrial hydrology, the continued evaluation/validation of these data (models and reanalysis) and space-borne measurements is advocated.

Acknowledgements The various agencies of government (National Oceanic and Atmospheric Administration, Center for Space Research, and National Aeronautics and Space Administration) are gratefully acknowledged for the data used to support this review paper. This synthesis contains items taken from the literature review component of the author's unpublished $\mathrm{PhD}$ thesis, which was completed at Curtin
University, Australia, in 2017. The comments of R W Abrams and two other anonymous reviewers, which helped improved the quality of the manuscript are gratefully acknowledged.

\section{Compliance with ethical standards}

Conflict of interest The author declares that there is no conflict of interest.

\section{References}

Agutu N, Awange J, Zerihun A, Ndehedehe C, Kuhn M, Fukuda Y (2017) Assessing multi-satellite remote sensing, reanalysis, and land surface models' products in characterizing agricultural drought in East Africa. Remote Sens Environ 194:287-302. https ://doi.org/10.1016/j.rse.2017.03.041

Ahmed M, Sultan M, Wahr J, Yan E (2014) The use of GRACE data to monitor natural and anthropogenic induced variations in water availability across Africa. Earth Sci Rev 136:289-300. https:// doi.org/10.1016/j.earscirev.2014.05.009

Alcamo J, Döll, P, Kaspar F, Siebert S (1997) Global change and global scenarios of water use and availability: an application of WaterGAP1.0. Center for Environmental Systems Research (CESR), University of Kassel, Germany. https://pdfs.semanticscholar.org/ a788/80a9f9952f0e04bc88c7c5699ea9c9e0fa30.pdf. Accessed 18 Aug 2016

Ali A, Lebel T (2009) The Sahelian standardized rainfall index revisited. Int J Climatol 29:1705-1714. https://doi.org/10.1002/ joc. 1832

Alley WM, Konikow LF (2015) Bringing GRACE down to earth. Groundwater 53(6):826-829. https://doi.org/10.1111/gwat.12379

Allison G, Cook P, Barnett S, Walker G, Jolly I, Hughes M (1990) Land clearance and river salinisation in the western Murray Basin, Australia. J Hydrol 119(1):1-20. https://doi.org/10.1016/00221694(90)90030-2

Alsdorf DE, Lettenmaier DP (2003) Tracking fresh water from space. Science 301(5639):1491-1494. https://doi.org/10.1126/scien ce. 1089802

Alsdorf D, Birkett C, Dunne T, Melack J, Hess L (2001) Water level changes in a large Amazon lake measured with spaceborne radar interferometry and altimetry. Geophys Res Lett 28(14):26712674. https://doi.org/10.1029/2001GL012962

Alsdorf D, Lettenmaier D, Vörösmarty C (2003) The need for global, satellite-based observations of terrestrial surface waters. Eos Trans Am Geophys Union 84(29):269-276. https://doi. org/10.1029/2003EO290001

Alsdorf DE, Rodríguez E, Lettenmaier DP (2007) Measuring surface water from space. Rev Geophys 45(2):RG2002. https://doi. org/10.1029/2006RG000197

Alsdorf D, Han S-C, Bates P, Melack J (2010) Seasonal water storage on the amazon floodplain measured from satellites. Remote Sens Environ 114(11):2448-2456. https://doi.org/10.1016/j. rse.2010.05.020

Alsdorf D, Beighley E, Laraque A, Lee H, Tshimanga R, O'Loughlin F, Mahé G, Dinga B, Moukandi G, Spencer RGM (2016) Opportunities for hydrologic research in the congo basin. Rev Geophys 54(2):378-409. https://doi.org/10.1002/2016RG000517

Andam-Akorful SA, Ferreira VG, Awange JL, Forootan E, He XF (2015) Multi-model and multi-sensor estimations of evapotranspiration over the Volta Basin, West Africa. Int J Climatol 35(10):3132-3145. https://doi.org/10.1002/joc.4198

Andam-Akorful S, Ferreira V, Ndehedehe CE, Quaye-Ballard J (2017) An investigation into the freshwater variability in West 
Africa during 1979 - 2010. Int J Climatol 37(S1):333-349. https://doi.org/10.1002/joc.5006

Anyadike RNC (1992) Hydrological regions of West Africa: a preliminary survey based on moisture regimes. Geogr Ann Ser A Phys Geogr 74(4):375-382. https://doi.org/10.2307/521433

Awange J, Anyah R, Agola N, Forootan E, Omondi P (2013a) Potential impacts of climate and environmental change on the stored water of Lake Victoria Basin and economic implications. Water Resour Res 49(0):8160-8173

Awange J, Forootan E, Kusche J, Kiema J, Omondi P, Heck B, Fleming K, Ohanya S, Gonçalves R (2013b) Understanding the decline of water storage across the Ramser-Lake Naivasha using satellite-based methods. Adv Water Resour 60:7-23. https://doi.org/10.1016/j.advwatres.2013.07.002

Bader J, Latif M (2011) The 1983 drought in the West Sahel: a case study. Clim Dyn 36(3-4):463-472. https://doi.org/10.1007/ s00382-009-0700-y

Balas N, Nicholson SE, Klotter D (2007) The relationship of rainfall variability in West Central Africa to sea-surface temperature fluctuations. Int J Climatol 27(10):1335-1349

Basu M (2009) West Africa flooding affects 600,000, U.N. reports. CNN. http://edition.cnn.com/2009/WORLD/africa/09/08/west. africa.flooding/index.html. Accessed 30 Aug 2017

Bekoe EO, Logah FY (2013) The impact of droughts and climate change on electricity generation in Ghana. Environ Sci $1(1): 13-24$

Birkett CM (1995) The contribution of TOPEX/POSEIDON to the global monitoring of climatically sensitive lakes. J Geophys Res Oceans 100(C12):25179-25204. https://doi. org/10.1029/95JC02125

Birkett CM (2000) Synergistic remote sensing of Lake Chad: variability of basin inundation. Remote Sens Environ 72:218-236. https://doi.org/10.1016/S0034-4257(99)00105-4

Boening C, Willis JK, Landerer FW, Nerem RS, Fasullo J (2012) The 2011 La Niña: So strong, the oceans fell. Geophys Res Lett 39(19):L19602. https://doi.org/10.1029/2012GL053055

Bonaccorso B, Bordi I, Cancelliere A, Rossi G, Sutera A (2003) Spatial variability of drought: an analysis of the SPI in Sicily. Water Resour Manag 17(4):273-296. https://doi. org/10.1023/A:1024716530289

Boone A, Decharme B, Guichard F, Rosnay PD, Balsamo G, Belaars A, Chopin F, Orgeval T, Polcher J, Delire C, Ducharne A, Gascoin S, Grippa M, Jarlan L, Kergoat L, Mougin E, Gusev Y, Nasonova O, Harris P, Taylor C, Norgaard A, Sandholt I, Ottle C, Poccard-Leclercq I, Saux-Picart S, Xue Y (2009) The AMMA land surface model intercomparison project (ALMIP). Bull Am Meteorol Soc 90(12):1865-1880. https:// doi.org/10.1175/2009BAMS27/86.1

Brauman KA, Richter BD, Postel S, Malsy M, Flörke M (2016) Water depletion: an improved metric for incorporating seasonal and dry-year water scarcity into water risk assessments. Elementa, 4(83). https://doi.org/10.12952/journal.elementa.00008 3

Brown C, Lall U (2006) Water and economic development: the role of variability and a framework for resilience. Natl Resour Forum 30(4):306-317

Cardoso J-F (1991) Super-symmetric decomposition of the fourthorder cumulant tensor, blind identification of more sources than sensors. http://perso.telecom-paristech.fr/ cardoso/Papers.PDF/ icassp91.pdf. Accessed 15 Jan 2016

Cardoso JF (1999) High-order contrasts for independent component analysis. Neural Comput 11:157-192

Cardoso JF, Souloumiac A (1993) Blind beamforming for non-gaussian signals. IEE Proc 140(6):362-370

Carrao H, Russo S, Sepulcre-Canto G, Barbosa P (2016) An empirical standardized soil moisture index for agricultural drought assessment from remotely sensed data. Int J Appl Earth Obs Geoinf 48:74-84. https://doi.org/10.1016/j.jag.2015.06.011

Castellazzi P, Martel R, Galloway DL, Longuevergne L, Rivera A (2016) Assessing groundwater depletion and dynamics using GRACE and InSAR: potential and limitations. Groundwater 54(6):768-780. https://doi.org/10.1111/gwat.12453

Chen JL, Rodell M, Wilson CR, Famiglietti JS (2005) Low degree spherical harmonic influences on gravity recovery and climate experiment (GRACE) water storage estimates. Geophys Res Lett 32(14):L14405. https://doi.org/10.1029/2005GL022964

Chen JL, Wilson CR, Tapley BD, Longuevergne L, Yang ZL, Scanlon BR (2010) Recent La Plata basin drought conditions observed by satellite gravimetry. J Geophys Res Atmos 115(D22):D22108. https://doi.org/10.1029/2010JD014689

Chen T, de Jeu R, Liu Y, van der Werf G, Dolman A (2014) Using satellite based soil moisture to quantify the water driven variability in NDVI: a case study over mainland Australia. Remote Sens Environ 140:330-338. https://doi.org/10.1016/j. rse.2013.08.022

Coe MT, Foley JA (2001) Human and natural impacts on the water resources of the Lake Chad basin. J Geophys Res 106(D4):33493356. https://doi.org/10.1029/2000JD900587

Conway D, Persechino A, Ardoin-Bardin S, Hamandawana H, Dieulin C, Mahé G (2009) Rainfall and water resources variability in Sub-Saharan Africa during the twentieth century. J Hydrometeorol 10(1):41-59. https://doi.org/10.1175/2008JHM1004.1

Cook KH, Vizy EK (2006) Coupled model simulations of the West African monsoon system: twentieth- and twenty-first-century simulations. J Clim 19(15):3681-3703. https://doi.org/10.1175/ JCLI3814.1

Corzo Perez GA, van Huijgevoort MHJ, Voß F, van Lanen HAJ (2011) On the spatio-temporal analysis of hydrological droughts from global hydrological models. Hydrol Earth Syst Sci 15(9):29632978. https://doi.org/10.5194/hess-15-2963-2011

Crowley JW, Mitrovica JX, Bailey RC, Tamisiea ME, Davis JL (2006) Land water storage within the Congo Basin inferred from GRACE satellite gravity data. Geophys Res Lett 33(19):L19402. https://doi.org/10.1029/2006GL027070

Dai A, Qian T, Trenberth KE, Milliman JD (2009) Changes in continental freshwater discharge from 1948 to 2004. J Clim 22(10):2773-2792. https://doi.org/10.1175/2008JCLI2592.1

Dardel C, Kergoat L, Hiernaux P, Mougin E, Grippa M, Tucker C (2014) Re-greening Sahel: 30 years of remote sensing data and field observations (Mali, Niger). Remote Sens Environ 140:350 364. https://doi.org/10.1016/j.rse.2013.09.011

de Giesen NV, Rodgers C, Vlek P (2007) The GLOWA Volta Project: Interdisciplinary analysis of the impact of global change on a river basin in West Africa. Int J River Basin Manag 5(1):3-8. https://doi.org/10.1080/15715124.2007.9635300

Descroix L, Mahé G, Lebel T, Favreau G, Galle S, Gautier E, Olivry J-C, Albergel J, Amogu O, Cappelaere B, Dessouassi R, Diedhiou A, Breton EL, Mamadou I, Sighomnou D (2009) Spatiotemporal variability of hydrological regimes around the boundaries between Sahelian and Sudanian areas of West Africa: a synthesis. J Hydrol 375(1-2):90-102. https://doi.org/10.1016/j. jhydrol.2008.12.012

Dirmeyer PA, Guo Z, Gao X (2004) Comparison, validation, and transferability of eight multiyear global soil wetness products. J Hydrometeorol 5:1011-1033. https://doi.org/10.1175/JHM-388.1

Do FC, Goudiaby VA, Gimenez O, Diagne AL, Diouf M, Rocheteau A, Akpo LE (2005) Environmental influence on canopy phenology in the dry tropics. For Ecol Manag 215(1-3):319-328. https:// doi.org/10.1016/j.foreco.2005.05.022

Döll P, Müller Schmied H, Schuh C, Portmann FT, Eicker A (2014) Global-scale assessment of groundwater depletion and related groundwater abstractions: combining hydrological modeling 
with information from well observations and GRACE satellites. Water Resour Res 50(7):5698-5720

Du L, Tian Q, Yu T, Meng Q, Jancso T, Udvardy P, Huang Y (2013) A comprehensive drought monitoring method integrating MODIS and TRMM data. Int J Appl Earth Obs Geoinf 23:245253. https://doi.org/10.1016/j.jag.2012.09.010

Erfanian A, Wang G, Yu M, Anyah R (2016) Multimodel ensemble simulations of present and future climates over West Africa: impacts of vegetation dynamics. J Adv Model Earth Syst. https ://doi.org/10.1002/2016MS000660

Falkenmark M, Lundqvist J (1998) Towards water security: political determination and human adaptation crucial. Natl Resour Forum 22(1):37-51. https://doi.org/10.1111/j.1477-8947.1998. tb00708.x

Falloon P, Betts R (2010) Climate impacts on European agriculture and water management in the context of adaptation and mitigation-the importance of an integrated approach. Sci Total Environ 408(23):5667-5687. https://doi.org/10.1016/j.scito tenv.2009.05.002

Famiglietti JS, Rodell M (2013) Water in the balance. Science 340(6138):1300-1301. https://doi.org/10.1126/science.12364 60

Famiglietti JS, Cazenave A, Eicker A, Reager JT, Rodell M, Velicogna I (2015) Satellites provide the big picture. Science 349(6249):684685. https://doi.org/10.1126/science.aac9238

Fan Y, Dool HV (2004) Climate prediction center global monthly soil moisture data set at $0.5^{\circ}$ resolution for 1948 to present. J Geophys Res 109:D10102. https://doi.org/10.1029/2003JD004345

Farnsworth A, White E, Williams CJ, Black E, Kniveton DR (2011) Understanding the large scale driving mechanisms of rainfall variability over Central Africa. In: African climate and climate change: physical, social and political perspectives, Springer, Netherlands, pp 101-122. https://doi. org/10.1007/978-90-481-3842-5_5.

Favreau G, Cappelaere B, Massuel S, Leblanc M, Boucher M, Boulain N, Leduc C (2009) Land clearing, climate variability, and water resources increase in semiarid southwest Niger: a review. Water Resour Res 45:W00A16. https://doi.org/10.1029/2007W R006785

Ferreira V, Asiah Z (2015) An investigation on the closure of the water budget methods over Volta Basin using multi-satellite data. Int Assoc Geodesy Symp. https://doi.org/10.1007/1345-2015-137

Ferreira V, Montecino H, Ndehedehe C, Heck B, Gong Z, Westerhaus M, de Freitas S (2018) Space-based observations of crustal deflections for drought characterization in Brazil. Sci Total Environ 644:256-273. https://doi.org/10.1016/j.scitotenv.2018.06.277

Fisher-Jeffes L, Carden K, Armitage NP, Winter K (2017) Stormwater harvesting: Improving water security in South Africa's urban areas. S Afr J Sci 113(1/2):4. https://doi.org/10.17159/ sajs.2017/20160153

Fontaine B, Bigot S (1993) West African rainfall deficits and sea surface temperatures. Int J Climatol 13(3):271-285. https://doi. org/10.1002/joc.3370130304

Forootan E, Kusche J, Loth I, Schuh WD, Eicker A, Awange J, Longuevergne L, Diekkruger B, Shum MSCK (2014) Multivariate prediction of total water storage changes over West Africa from multi-satellite data. Surv Geophys 35(4):913-940. https:// doi.org/10.1007/s10712-014-9292-0

Frappart F, Calmant S, Cauhopé M, Seyler F, Cazenave A (2006) Preliminary results of ENVISAT RA-2-derived water levels validation over the Amazon basin. Remote Sens Environ 100(2):252264. https://doi.org/10.1016/j.rse.2005.10.027

Freitas A (2013) Water as a stress factor in sub-Saharan Africa. In: European union institute for security studies, pp 1-4. http:// www.iss.europa.eu/uploads/media/Brief_12.pdf. Accessed 12 July 2017
Funk C, Peterson P, Landsfeld M, Pedreros D, Verdin J, Shukla S, Husak G, Rowland J, Harrison L, Hoell A, Michaelsen J (2015) The climate hazards infrared precipitation with stations-a new environmental record for monitoring extremes. Sci Data 2:150066. https://doi.org/10.1038/sdata.2015.66

Gal L, Grippa M, Hiernaux P, Pons L, Kergoat L (2017) The paradoxical evolution of runoff in the pastoral Sahel: analysis of the hydrological changes over the Agoufou watershed (Mali) using the KINEROS-2 model. Hydrol Earth Syst Sci 21(9):4591-4613. https://doi.org/10.5194/hess-21-4591-2017

Giannini A, Saravanan R, Chang P (2003) Oceanic forcing of Sahel rainfall on interannual to decadal time scales. Science 302(5647):1027-1030. https://doi.org/10.1126/science.1089357

Gizaw MS, Gan TY (2017) Impact of climate change and El Niño episodes on droughts in sub-Saharan Africa. Clim Dyn 49(1):665682. https://doi.org/10.1007/s00382-016-3366-2

Gleick PH (1993) Water and conflict: fresh water resources and international security. Int Secur 18(1):79-112. https://doi. org/10.2307/2539033

Gleick PH (2000) The world's water: Biennial report on freshwater resources 2000-2001. Island Press, Washington, DC

Goncàlves J, Peterson J, Deschamps P, Hamelin B, Baba-Sy O (2013) Quantifying the modern recharge of the "fossil" Sahara aquifers. Geophys Res Lett 40:2673-2678. https://doi.org/10.1002/ grl.50478

Grippa M, Kergoat L, Frappart F, Araud Q, Boone A, de Rosnay P, Lemoine JM, Gascoin S, Balsamo G, Ottlé C, Decharme B, Saux-Picart S, Ramillien G (2011) Land water storage variability over West Africa estimated by gravity recovery and climate experiment (GRACE) and land surface models. Water Resour Res 47(5):W05549. https://doi.org/10.1029/2009wr008856

Guan K, Wood EF, Medvigy D, Kimball J, Pan M, Caylor KK, Sheffield J, Xu X, Jones MO (2014) Terrestrial hydrological controls on land surface phenology of African savannas and woodlands. J Geophys Res Biogeosci 119(8):1652-1669. https://doi. org/10.1002/2013JG002572

Guan K, Sultan B, Biasutti M, Baron C, Lobell DB (2015) What aspects of future rainfall changes matter for crop yields in West Africa? Geophys Res Lett 42(19):8001-8010. https://doi. org/10.1002/2015GL063877

Hall JW, Grey D, Garrick D, Fung F, Brown C, Dadson SJ, Sadoff CW (2014) Coping with the curse of freshwater variability. Science 346(6208):429-430. https://doi.org/10.1126/science.1257890

Hayes MJ, Svoboda MD, Wilhite DA, Vanyarkho OV (1999) Monitoring the 1996 drought using the standardized precipitation index. Bull Am Meteorol Soc 80:429-438

Heim RR (2002) A review of twentieth-century drought indices used in the United States. Bull Am Meteorol Soc 83(8):1149-1165

Hély C, Bremond L, Alleaume S, Smith B, Sykes MT, Guiot J (2006) Sensitivity of African biomes to changes in the precipitation regime. Glob Ecol Biogeogr 15(3):258-270. https://doi.org/10 $.1111 /$ j.1466-8238.2006.00235.x

Henry C, Allen DM, Huang J (2011) Groundwater storage variability and annual recharge using well-hydrograph and GRACE satellite data. Hydrogeol J 19:741-755. https://doi.org/10.1007/s1004 0-011-0724-3

Herrmann SM, Anyamba A, Tucker CJ (2005) Recent trends in vegetation dynamics in the African Sahel and their relationship to climate. Glob Environ Change 15(4):394-404. https://doi. org/10.1016/j.gloenvcha.2005.08.004

Hinderer J, de Linage C, Boya J-P, Gegout P, Masson F, Rogister Y, Amalvict M, Pfeffer J, Littel F, Luck B, Bayerb R, Champollion C, Collard P, Moigne NL, Diamentc M, Deroussi S, de Viron O, Biancale R, Lemoine J-M, Bonvalot S, Gabalda G, Bock O, Genthon P, Boucher M, Favreau G, Séguis L, Delclaux F, Cappelaere B, Oi M, Descloitresh M, Galleh S, Laurent J-P, Legchenko 
A, Bouink M-N (2009) The GHYRAF (Gravity and Hydrology in Africa) experiment: description and first results. J Geodyn 48:172-181. https://doi.org/10.1016/j.jog.2009.09.014

Hoff H (2009) Global water resources and their management. Curr Opin Environ Sustain 1(2):141-147. https://doi.org/10.1016/j. cosust.2009.10.001

Houborg R, Rodell M, Li B, Reichle R, Zaitchik BF (2012) Drought indicators based on model-assimilated gravity recovery and climate experiment (GRACE) terrestrial water storage observations. Water Resour Res 48(7):W07525. https://doi.org/10.1029/2011W R011291

Hua W, Zhou L, Chen H, Nicholson SE, Raghavendra A, Jiang Y (2016) Possible causes of the central equatorial African longterm drought. Environ Res Lett 11(12):124002. https://doi. org/10.1088/1748-9326/11/12/124002

Huber S, Fensholt R, Rasmussen K (2011) Water availability as the driver of vegetation dynamics in the African Sahel from 1982 to 2007. Glob Planet Change 76(3-4):186-195. https://doi. org/10.1016/j.gloplacha.2011.01.006

Humphrey V, Gudmundsson L, Seneviratne SI (2016) Assessing global water storage variability from GRACE: trends, seasonal cycle, subseasonal anomalies and extremes. Surv Geophys 37(2):357395. https://doi.org/10.1007/s10712-016-9367-1

Ivits E, Horion S, Fensholt R, Cherlet M (2014) Drought footprint on European ecosystems between 1999 and 2010 assessed by remotely sensed vegetation phenology and productivity. Glob Change Biol 20(2):581-593. https://doi.org/10.1111/gcb.12393

Janicot S (1992) Spatiotemporal variability of West African rainfall. Part i: regionalizations and typings. J Clim 5(5):489-497

Jenkins GS, Adamou G, Fongang S (2002) The challenges of modeling climate variability and change in West Africa. Clim Change 52(3):263-286. https://doi.org/10.1023/A:1013741803144

Kasei R, Diekkrüger B, Leemhuis C (2010) Drought frequency in the Volta Basin of West Africa. Sustain Sci 5(1):89-97

Knauer K, Gessner U, Dech S, Kuenzer C (2014) Remote sensing of vegetation dynamics in West Africa. Int $\mathrm{J}$ Remote Sens 35(17):6357-6396. https://doi.org/10.1080/01431 161.2014.954062

Koster RD, Dirmeyer PA, Guo Z, Bonan G, Chan E, Cox P, Gordon CT, Kanae S, Kowalczyk E, Lawrence D, Liu P, Lu C-H, Malyshev S, McAvaney B, Mitchell K, Mocko D, Oki T, Oleson K, Pitman A, Sud YC, Taylor CM, Verseghy D, Vasic R, Xue Y, Yamada T (2004) Regions of strong coupling between soil moisture and precipitation. Science 305(5687):1138-1140. https://doi. org/10.1126/science.1100217

Kumar KN, Rajeevan M, Pai D, Srivastava A, Preethi B (2013) On the observed variability of monsoon droughts over India. Weather Clim Extremes 1:42-50. https://doi.org/10.1016/j. wace.2013.07.006

Kurnik B, Kajfež-Bogataj L, Horion S (2015) An assessment of actual evapotranspiration and soil water deficit in agricultural regions in Europe. Int J Climatol 35(9):2451-2471. https://doi.org/10.1002/ joc. 4154

Kuylenstierna JL, Björklund G, Najlis P (1997) Sustainable water future with global implications: everyone's responsibility. Natl Resour Forum 21(3):181-190. https://doi. org/10.1111/j.1477-8947.1997.tb00691.x

Lammers RB, Shiklomanov AI, Vörösmarty CJ, Fekete BM, Peterson BJ (2001) Assessment of contemporary Arctic river runoff based on observational discharge records. J Geophys Res Atmos 106(D4):3321-3334. https://doi.org/10.1029/2000JD900444

Laux P (2009) Statistical modeling of precipitation for agricultural planning in the Volta Basin of West Africa. Doctoral dissertation, Mitteilungen/Institut für Wasserbau, Universität Stuttgart, 179(198). https://elib.uni-stuttgart.de/opus/volltexte/2009/4016/ pdf/Dissertation-Laux.pdf. Accessed 25 July 2014
Lebel T, Ali A (2009) Recent trends in the Central and Western Sahel rainfall regime (1990-2007). J Hydrol 375(1-2):52-64. https ://doi.org/10.1016/j.jhydrol.2008.11.030

Lebel T, Delclaux F, Le Barbé L, Polcher J (2000) From GCM scales to hydrological scales: rainfall variability in West Africa. Stoch Environ Res Risk Assess 14(4):275-295. https://doi. org/10.1007/s004770000050

Lebel T, Cappelaere B, Galle S, Hanan N, Kergoat L, Levis S, Vieux B, Descroix L, Gosset M, Mougin E, Peugeot C, Seguis L (2009) AMMA-CATCH studies in the Sahelian region of WestAfrica: an overview. J Hydrol 375(1-2):3-13

Leblanc M, Leduc C, Razack M, Lemoalle J, Dagorne D, Mofor L (2003) Applications of remote sensing and GIS for groundwater modelling of large semiarid areas: example of the Lake Chad Basin, Africa. In: Proceedings of the international symposium held at Montpellier, hydrology of the mediterranean and semiarid regions, vol 278, pp 186-191, April 2003

Leduc C, Bromley J, Schroeter P (1997) Water table fluctuation and recharge in semi-arid climate: some results of the HAPEXSahel hydrodynamic survey (Niger). J Hydrol 188(188189):123-138. https://doi.org/10.1016/S0022-1694(96)03156 $-3$

Leduc C, Favreau G, Schroeter P (2001) Long-term rise in a Sahelian water-table: the continental terminal in south-west Niger. J Hydrol 243(1-2):43-54. https://doi.org/10.1016/S0022 $-1694(00) 00403-0$

Lee H, Beighley RE, Alsdorf D, Jung HC, Shum C, Duan J, Guo J, Yamazaki D, Andreadis K (2011) Characterization of terrestrial water dynamics in the Congo Basin using GRACE and satellite radar altimetry. Remote Sens Environ 115(12):35303538. https://doi.org/10.1016/j.rse.2011.08.015

Lee H, Jung HC, Yuan T, Beighley RE, Duan J (2014) Controls of terrestrial water storage changes over the Central Congo Basin determined by integrating Palsar ScanSar, Envisat Altimetry, and Grace data. Remote Sens Terr Water Cycle Geophys Monogr 206:117-129. https://doi.org/10.1002/9781118872086.ch7/ pdf

Lemoalle J, Bader J-C, Leblanc M, Sedick A (2012) Recent changes in Lake Chad: observations, simulations and management options (1973-2011). Glob Planet Change 80-81:247-254. https://doi. org/10.1016/j.gloplacha.2011.07.004

Lettenmaier DP (2005) Observations of the global water cycle-global monitoring networks. In: Anderson MG (ed) Encyclopedia of hydrological sciences, vol 5. Wiley, New York, pp 2719-2732

Li B, Rodell M (2015) Evaluation of a model-based groundwater drought indicator in the conterminous U.S. J Hydrol 526:78-88. https://doi.org/10.1016/j.jhydrol.2014.09.027

Li KY, Coe MT, Ramankutty N (2005) Investigation of hydrological variability in West Africa using land surface models. J Clim 18(16):3173-3188. https://doi.org/10.1175/JCLI3452.1

Li K, Coe M, Ramankutty N, Jong RD (2007) Modeling the hydrological impact of land-use change in West Africa. J Hydrol 337(34):258-268. https://doi.org/10.1016/j.jhydrol.2007.01.038

Long D, Scanlon BR, Longuevergne L, Sun AY, Fernando DN, Save H (2013) GRACE satellite monitoring of large depletion in water storage in response to the 2011 drought in Texas. Geophys Res Lett 40(13):3395-3401. https://doi.org/10.1002/Grl.50655

Long D, Shen Y, Sun A, Hong Y, Longuevergne L, Yang Y, Li B, Chen L (2014) Drought and flood monitoring for a large karst plateau in southwest china using extended GRACE data. Remote Sens Environ 155:145-160. https://doi.org/10.1016/j.rse.2014.08.006

Lopez T, Antoine R, Kerr Y, Darrozes J, Rabinowicz M, Ramillien G, Cazenave A, Genthon P (2016) Subsurface hydrology of the Lake Chad Basin from convection modelling and observations. Surv Geophys 37(2):471-502. https://doi.org/10.1007/s1071 2-016-9363-5 
Lovett JC, Midgley GF, Barnard P (2005) Climate change and ecology in africa. Afr J Ecol 43(3):167-169. https://doi.org/10.111 $1 /$ j.1365-2028.2005.00598.x

Mahé G, Olivry J-C (1999) Assessment of freshwater yields to the ocean along the intertropical Atlantic coast of Africa (19511989). Comptes Rendus de l'Académie des Sciences-Ser IIAEarth Planet Sci 328(9):621-626. https://doi.org/10.1016/S1251 $-8050(99) 80159-1$

Mahé G, Paturel J-E (2009) 1896-2006 Sahelian annual rainfall variability and runoff increase of Sahelian Rivers. Comptes Rendus Geosci 341(7):538-546. https://doi.org/10.1016/j. crte.2009.05.002

Mahe G, Lienou G, Descroix L, Bamba F, Paturel JE, Laraque A, Meddi M, Habaieb H, Adeaga O, Dieulin C, Chahnez Kotti F, Khomsi K (2013) The rivers of Africa: witness of climate change and human impact on the environment. Hydrol Process 27(15):2105-2114

McCabe MF, Rodell M, Alsdorf DE, Miralles DG, Uijlenhoet R, Wagner W, Lucieer A, Houborg R, Verhoest NEC, Franz TE, Shi J, Gao H, Wood EF (2017) The future of Earth observation in hydrology. Hydrol Earth Syst Sci 21(7):3879-3914. https://doi. org/10.5194/hess-21-3879-2017

McKee TB, Doeskin NJ, Kieist J (1993) The relationship of drought frequency and duration to time scales. In: Conference on applied climatology, American meteorological society, Boston, MA, pp 179-184. www.ccc.atmos.colostate.edu/relationshipofdrough tfrequency.pdf. Accessed 27 June 2014

Mehr AD, Kahya E, Ozger M (2014) A gene-wavelet model for long lead time drought forecasting. J Hydrol 517:691-699. https://doi. org/10.1016/j.jhydrol.2014.06.012

Mishra AK, Ines AV, Das NN, Khedun CP, Singh VP, Sivakumar B, Hansen JW (2015) Anatomy of a local-scale drought: Application of assimilated remote sensing products, crop model, and statistical methods to an agricultural drought study. J Hydrol 526:15-29. https://doi.org/10.1016/j.jhydrol.2014.10.038

Mohino E, Janicot S, Bader J (2011) Sahel rainfall and decadal to multi-decadal sea surface temperature variability. Clim Dyn 37:419-440. https://doi.org/10.1007/s00382-010-0867-2

Moore P, Williams SDP (2014) Integration of altimetry lake levels and GRACE gravimetry over Africa: Inferences for terrestrial water storage change 2003-2011. Water Resour Res 50:9696-9720. https://doi.org/10.1002/2014WR015506

Nahmani S, Bock O, Bouin M-N, Santamaría-Gómez A, Boy J-P, Collilieux X, Métivier L, Isabelle Panet PG, de Linage C, Wöppelmann G (2012) Hydrological deformation induced by the West African Monsoon: comparison of GPS, GRACE and loading models. J Geophys Res Solid Earth. https://doi. org/10.1029/2011JB009102

NASA (2002). Grace launch. National Aeronautics And Space Administration. http://www.jpl.nasa.gov/news/press-kits/gracelaunc h.pdf Accessed 9 Feb 2017

Ndehedehe CE (2017) Remote sensing of West Africa's water resources using multi-satellites and models. $\mathrm{PhD}$ thesis, Curtin University, Bentley, Perth, Western Australia. http://hdl.handl e.net/20.500.11937/59637. Accessed 12 Jan 2018

Ndehedehe C, Awange J, Agutu N, Kuhn M, Heck B (2016a) Understanding changes in terrestrial water storage over West Africa between 2002 and 2014. Adv Water Resour 88:211-230. https ://doi.org/10.1016/j.advwatres.2015.12.009

Ndehedehe CE, Agutu NO, Okwuashi OH, Ferreira VG (2016b) Spatio-temporal variability of droughts and terrestrial water storage over Lake Chad Basin using independent component analysis. J Hydrol 540:106-128. https://doi.org/10.1016/j.jhydr ol.2016.05.068

Ndehedehe CE, Awange JL, Corner R, Kuhn M, Okwuashi O (2016c) On the potentials of multiple climate variables in assessing the spatio-temporal characteristics of hydrological droughts over the Volta Basin. Sci Total Environ 557-558:819-837. https://doi. org/10.1016/j.scitotenv.2016.03.004

Ndehedehe CE, Awange J, Kuhn M, Agutu N, Fukuda Y (2017a) Analysis of hydrological variability over the Volta river basin using in-situ data and satellite observations. J Hydrol Reg Stud 12:88-110. https://doi.org/10.1016/j.ejrh.2017.04.005

Ndehedehe CE, Awange J, Kuhn M, Agutu N, Fukuda Y (2017b) Climate teleconnections influence on West Africa's terrestrial water storage. Hydrol Process 31(18):3206-3224. https://doi. org/10.1002/hyp.11237

Ndehedehe CE, Agutu NO, Okwuashi O (2018a) Is terrestrial water storage a useful indicator in assessing the impacts of climate variability on crop yield in semi-arid ecosystems? Ecol Indic 88C:51-62. https://doi.org/10.1016/j.ecolind.2018.01.026

Ndehedehe CE, Awange JL, Agutu NO, Okwuashi O (2018b) Changes in hydro-meteorological conditions over tropical West Africa (1980 - 2015) and links to global climate. Glob Planet Change 162:321-341. https://doi.org/10.1016/j.gloplacha.2018.01.020

Ndehedehe CE, Okwuashi O, Ferreira VG, Agutu NO (2018c) Exploring evapotranspiration dynamics over sub-Sahara Africa (2000 - 2014). Environ Monit Assess 190(7):400. https://doi. org/10.1007/s10661-018-6780-6

Ndehedehe CE, Anyah RO, Alsdorf D, Agutu NO, Ferreira VG (2019) Modelling the impacts of global multi-scale climatic drivers on hydro-climatic extremes (1901-2014) over the congo basin. Sci Total Environ 651:1569-1587. https://doi.org/10.1016/j.scito tenv.2018.09.203

Ngom F, Tweed S, Bader J-C, Saos J-L, Malou R, Leduc C, Leblanc M (2016) Rapid evolution of water resources in the Senegal delta. Glob Planet Change 144:34-47. https://doi.org/10.1016/j.glopl acha.2016.07.002

Ni S, Chen J, Wilson CR, Li J, Hu X, Fu R (2017) Global terrestrial water storage changes and connections to ENSO events. Surv Geophys. https://doi.org/10.1007/s10712-017-9421-7

Nicholson S (2005) On the question of the "recovery" of the rains in the West African Sahel. J Arid Environ 63(3):615-641. https:// doi.org/10.1016/j.jaridenv.2005.03.004

Nicholson S (2013) The West African Sahel: a review of recent studies on the rainfall regime and its interannual variability. ISRN Meteorol 2013(453521):1-32. https://doi.org/10.1155/2013/453521

Nicholson SE (2014) Spatial teleconnections in African rainfall: a comparison of 19th and 20th century patterns. Holocene 24(12):1840-1848. https://doi.org/10.1177/0959683614551230

Nicholson SE, Davenport ML, Malo AR (1990) A comparison of the vegetation response to rainfall in the Sahel and East Africa, using normalized difference vegetation index from NOAA AVHRR. Clim Change 17(2):209-241. https://doi.org/10.1007/BF001 38369

Nicholson SE, Some B, Kone B (2000) An analysis of recent rainfall conditions in West Africa, including the rainy seasons of the 1997 El Nin̈o and the 1998 La Niña years. J Clim 13(14):2628-2640

Nicholson SE, Some B, Mccollum J, Nelkin E, Klotter D, Berte Y, Diallo BM, Gaye I, Kpabeba G, Ndiaye O, Noukpozounkou JN, Tanu MM, Thiam A, Toure AA, Traore AK (2003) Validation of TRMM and other rainfall estimates with a high-density gauge datasets for West Africa. Part I: validation of GPCC rainfall product and pre-TRMM satellite and blended products. J Appl Meteorol 42:1337-1354. https://doi.org/10.1175/15200450(2003)042C1337:VOTAOR3E2.0.CO;2

Niu J, Chen J, Sun L (2015) Exploration of drought evolution using numerical simulations over the Xijiang (West River) basin in South China. J Hydrol 526:68-77. https://doi.org/10.1016/j.jhydr ol.2014.11.029

Nka BN, Oudin L, Karambiri H, Paturel JE, Ribstein P (2015) Trends in floods in West Africa: analysis based on 11 catchments in 
the region. Hydrol Earth Syst Sci 19(11):4707-4719. https://doi. org/10.5194/hess-19-4707-2015

Oettli P, Sultan B, Baron C, Vrac M (2011) Are regional climate models relevant for crop yield prediction in West Africa? Environ Res Lett 6(1):014008. https://doi.org/10.1088/1748-9326/6/1/014008

Okonkwo C (2014) An advanced review of the relationships between Sahel precipitation and climate indices: a wavelet approach. Int J Atmos Sci 2014:11. https://doi.org/10.1155/2014/759067

Oloruntade AJ, Mohammad TA, Ghazali AH, Wayayok A (2017) Analysis of meteorological and hydrological droughts in the NigerSouth Basin, Nigeria. Glob Planet Change 155(Supplement C):225-233. https://doi.org/10.1016/j.gloplacha.2017.05.002

Otto FEL, Jones RG, Halladay K, Allen MR (2013) Attribution of changes in precipitation patterns in African rainforests. Philos Trans R Soc Lond B Biol Sci 368(1625):20120299. https://doi. org/10.1098/rstb.2012.0299

Owusu K, Waylen P (2009) Trends in spatio-temporal variability in annual rainfall in Ghana (1951-2000). Weather 64(5):115-119

Paeth H, Fink A, Pohle S, Keis F, Machel H, Samimi C (2012) Meteorological characteristics and potential causes of the 2007 flood in sub-Saharan Africa. Int J Climatol 31:1908-1926. https://doi. org/10.1002/Joc.2199

Panthou G, Vischel T, Lebel T (2014) Recent trends in the regime of extreme rainfall in the central sahel. Int J Climatol 34(15):39984006. https://doi.org/10.1002/joc.3984

Paolino DA, Kinter JL III, Kirtman BP, Min D, Straus DM (2012) The impact of land surface and atmospheric initialization on seasonal forecasts with CCSM. J Clim 25(3):1007-1021. https://doi. org/10.1175/2011JCLI3934.1

Paturel J-E, Ouedraogo M, Servat E, Mahe G, Dezetter A, Boyer J-F (2003) The concept of rainfall and streamflow normals in West and Central Africa in a context of climatic variability. Hydrol Sci J 48(1):125-137. https://doi.org/10.1623/hysj.48.1.125.43479

Paturel JE, Mahé G, Diello P, Barbier B, Dezetter A, Dieulin C, Karambiri H, Yacouba H, Maiga A (2017) Using land cover changes and demographic data to improve hydrological modeling in the Sahel. Hydrol Process 31(4):811-824. https://doi.org/10.1002/ hyp. 11057

Pellarin T, Tran T, Cohard J-M, Galle S, Laurent J-P, de Rosnay P, Vischel T (2009) Soil moisture mapping over West Africa with a 30-min temporal resolution using AMSR-E observations and a satellite-based rainfall product. Hydrol Earth Syst Sci 13(10):1887-1896. https://doi.org/10.5194/hess-13-1887-2009

Petropoulos GP, Ireland G, Barrett B (2015) Surface soil moisture retrievals from remote sensing: current status, products, and future trends. Phys Chem Earth, Parts A/B/C 83-84:36-56. https ://doi.org/10.1016/j.pce.2015.02.009

Phillips T, Nerem RS, Fox-Kemper B, Famiglietti JS, Rajagopalan B (2012) The influence of ENSO on global terrestrial water storage using GRACE. Geophys Res Lett 39(L16705):2012. https://doi. org/10.1029/2012GL052495

Piao S, Ciais P, Huang Y, Shen Z, Peng S, Li J, Zhou L, Liu H, Ma Y, Friedlingstein P, Liu C, Tan K, Yu Y, Zhang T, Fang J (2010) The impacts of climate change on water resources and agriculture in China. Nature 467:43-51. https://doi.org/10.1038/nature09364

Pierre C, Grippa M, Mougin E, Guichard F, Kergoat L (2016) Changes in Sahelian annual vegetation growth and phenology since 1960: a modeling approach. Glob Planet Change 143:162-174. https:// doi.org/10.1016/j.gloplacha.2016.06.009

Preisendorfer R (1988) Principal component analysis in meteorology and oceanography. Developments in atmospheric science, vol 17. Elsevier, Amsterdam

Prudhomme C, Giuntoli I, Robinson EL, Clark DB, Arnell NW, Dankers R, Fekete BM, Franssen W, Gerten D, Gosling SN, Hagemann S, Hannah DM, Kim H, Masaki Y, Satoh Y, Stacke T, Wada Y, Wisser D (2014) Hydrological droughts in the 21st century, hotspots and uncertainties from a global multimodel ensemble experiment. Proc Natl Acad Sci 111(9):3262-3267. https://doi.org/10.1073/pnas.1222473110

Ramillien G, Bouhours S, Lombard A, Cazenave A, Flechtner FR, Schmidt (2008) Land water storage contribution to sea level from GRACE geoid data over 2003-2006. Glob Planet Change 60(3-4):381-392. https://doi.org/10.1016/j.glopl acha.2007.04.002

Reager JT, Thomas BF, Famiglietti JS (2014) River basin flood potential inferred using GRACE gravity observations at several months lead time. Nat Geosci 7(8):588-592. https://doi. org/10.1038/ngeo2203

Reichle RH, Koster RD, Lannoy GJMD, Forman BA, Liu Q, Mahanama SPP, Touré A (2011) Assessment and enhancement of MERRA land surface hydrology estimates. J Clim 24(24):6322-6338. https://doi.org/10.1175/JCLI-D-10-05033.1

Rienecker MM, Suarez MJ, Gelaro R, Todling R, Bacmeister J, Liu E, Bosilovich MG, Schubert SD, Takacs L, Kim G-K, Bloom S, Chen J, Collins D, Conaty A, da Silva A, Gu W, Joiner J, Koster RD, Lucchesi R, Molod A, Owens T, Pawson S, Pegion P, Redder CR, Reichle R, Robertson FR, Ruddick AG, Sienkiewicz M, Woollen J (2011) MERRA: NASA's modern-era retrospective analysis for research and applications. J Clim 24(14):3624-3648. https://doi.org/10.1175/JCLI-D-11-00015.1

Rijsberman FR (2006) Water scarcity: fact or fiction? Agric Water Manag 80(1-3):5-22. https://doi.org/10.1016/j.agwat .2005 .07 .001

Rodell M, Houser PR, Jambor U, Gottschalck J, Mitchell K, Meng K, Arsenault CJ, Cosgrove B, Radakovich J, Bosilovich M, Entin JK, Walker JP, Lohmann D, Toll D (2004) The global land data assimilation system. Bull Am Meteorol Soc 85(3):381-394. https ://doi.org/10.1175/BAMS-85-3-381.R

Rouault M, Richard Y (2003) Intensity and spatial extension of drought in South Africa at different time scales. Water SA 29(4):489-500

Roudier P, Sultan B, Quirion P, Berg A (2011) The impact of future climate change on West African crop yields: what does the recent literature say? Glob Environ Change 21:1073-1083. https://doi. org/10.1016/j.gloenvcha.2011.04.007

Roudier P, Ducharne A, Feyen L (2014) Climate change impacts on runoff in west africa: a review. Hydrol Earth Syst Sci 18(7):2789 2801. https://doi.org/10.5194/hess-18-2789-2014

Sanogo S, Fink AH, Omotosho JA, Ba A, Redl R, Ermert V (2015) Spatio-temporal characteristics of the recent rainfall recovery in West Africa. Int J Climatol 35(15):4589-4605. https://doi. org/10.1002/joc.4309

Santos JF, Pulido-Calvo I, Portela MM (2010) Spatial and temporal variability of droughts in Portugal. Water Resour Res 46(3):W03503. https://doi.org/10.1029/2009WR008071

Scanlon BR, Reedy RC, Stonestrom DA, Prudic DE, Dennehy KF (2005) Impact of land use and land cover change on groundwater recharge and quality in the southwestern US. Glob Change Biol 11(10):1577-1593. https://doi.org/10.111 1/j.1365-2486.2005.01026.x

Schewe J, Heinke J, Gerten D, Haddeland I, Arnell NW, Clark DB, Dankers R, Eisner S, Fekete BM, Colón-González FJ, Gosling SN, Kim H, Liu X, Masaki Y, Portmann FT, Satoh Y, Stacke T, Tang Q, Wada Y, Wisser D, Albrecht T, Frieler K, Piontek F, Warszawski L, Kabat P (2013) Multimodel assessment of water scarcity under climate change. PNAS 111(9):3245-3250. https ://doi.org/10.1073/pnas.1222460110

Schuol J, Abbaspour KC (2006) Calibration and uncertainty issues of a hydrological model (SWAT) applied to West Africa. Adv Geosci 9:137-143

Seghieri J, Carreau J, Boulain N, De Rosnay P, Arjounin M, Timouk F (2012) Is water availability really the main environmental factor controlling the phenology of woody vegetation in the central 
Sahel? Plant Ecol 213(5):861-870. https://doi.org/10.1007/s1125 8-012-0048-y

Séguis L, Cappelaere B, Milési G, Peugeot C, Massuel S, Favreau G (2004) Simulated impacts of climate change and land-clearing on runoff from a small Sahelian catchment. Hydrol Process 18(17):3401-3413. https://doi.org/10.1002/hyp.1503

Semazzi FHM, Mehta V, Sud Y (1988) An investigation of the relationship between sub-Saharan rainfall and global sea surface temperatures. Atmos Ocean 26(1):118-138. https://doi. org/10.1080/07055900.1988.9649293

Senay GB, Velpuri NM, Bohms S, Demissie Y, Gebremichael M (2014) Understanding the hydrologic sources and sinks in the Nile Basin using multisource climate and remote sensing data sets. Water Resour Res 50(11):8625-8650. https://doi.org/10.1002/2013W R015231

Sheffield J, Wood EF (2008) Global trends and variability in soil moisture and drought characteristics, 1950-2000, from observationdriven simulations of the terrestrial hydrologic cycle. J Clim 21(3):432-458. https://doi.org/10.1175/2007JCLI1822.1

Sheffield J, Ferguson CR, Troy TJ, Wood EF, McCabe MF (2009) Closing the terrestrial water budget from satellite remote sensing. Geophys Res Lett 36(7):L07403

Sheffield J, Wood EF, Chaney N, Guan K, Sadri S, Yuan X, Olang L, Amani A, Ali A, Demuth S, Ogallo L (2014) A drought monitoring and forecasting system for Sub-Sahara African water resources and food security. Bull Am Meteorol Soc 95(6):861882. https://doi.org/10.1175/BAMS-D-12-00124.1

Shiferaw B, Tesfaye K, Kassie M, Abate T, Prasanna B, Menkir A (2014) Managing vulnerability to drought and enhancing livelihood resilience in sub-Saharan Africa: technological, institutional and policy options. Weather Clim Extremes 3:67-79. https ://doi.org/10.1016/j.wace.2014.04.004

Shiklomanov IA (2000) Appraisal and assessment of world water resources. Water Int 25(1):11-32. https://doi.org/10.1080/02508 060008686794

Singh A, Kulkarni MA, Mohanty UC, Kar SC, Robertson AW, Mishra G (2012) Prediction of Indian summer monsoon rainfall (ISMR) using canonical correlation analysis of global circulation model products. Meteorol Appl 19(2):179-188. https://doi.org/10.1002/ met. 1333

Sneeuw N, Lorenz C, Devaraju B, Tourian M, Riegger J, Kunstmann H, Bárdossy A (2014) Estimating runoff using hydro-geodetic approaches. Surv Geophys 35(6):1333-1359. https://doi. org/10.1007/s10712-014-9300-4

Spinoni J, Naumann G, Carrao H, Barbosa P, Vogt J (2014) World drought frequency, duration, and severity for 1951-2010. Int J Climatol 34(8):2792-2804. https://doi.org/10.1002/joc.3875

Swenson S, Wahr J (2002) Methods for inferring regional surfacemass anomalies from gravity recovery and climate experiment (GRACE) measurements of time-variable gravity. J Geophys Res Solid Earth. https://doi.org/10.1029/2001jb000576

Swenson S, Wahr J (2007) Multi-sensor analysis of water storage variations of the Caspian Sea. Geophys Res Lett. https://doi. org/10.1029/2007g1030733

Tall M, Sylla MB, Diallo I, Pal JS, Faye A, Mbaye ML, Gaye AT (2016) Projected impact of climate change in the hydroclimatology of Senegal with a focus over the Lake of Guiers for the twenty-first century. Theor Appl Climatol. https://doi.org/10.1007/s0070 4-016-1805-y

Tapley B, Bettadpur S, Watkins M, Reigber C (2004) The gravity recovery and climate experiment: mission overview and early results. Geophys Res Lett 31:1-4. https://doi.org/10.1029/2004G L019920

Tarhule A, Zume JT, Grijsen J, Talbi-Jordan A, Guero A, Dessouassi RY, Doffou H, Kone S, Coulibaly B, Harshadeep NR (2015) Exploring temporal hydroclimatic variability in the
Niger Basin (1901-2006) using observed and gridded data Int J Climatol 35(4):520-539. https://doi.org/10.1002/joc.3999

Thiemig V, Rojas R, Zambrano-Bigiarini M, Roo AD (2013) Hydrological evaluation of satellite-based rainfall estimates over the Volta and Baro-Akobo Basin. J Hydrol 499:324-338. https:// doi.org/10.1016/j.jhydrol.2013.07.012

Thomas AC, Reager JT, Famiglietti JS, Rodell M (2014) A GRACEbased water storage deficit approach for hydrological drought characterization. Geophys Res Lett 41(5):1537-1545. https:// doi.org/10.1002/2014GL059323

Tiwari VM, Wahr J, Swenson S (2009) Dwindling groundwater resources in northern India, from satellite gravity observations. Geophys Res Lett 36(18):L18401. https://doi. org/10.1029/2009GL039401

Todd M, Andersson L, Ambrosino C, Hughes D, Kniveton DR, Mileham L, Murray-Hudson M, Raghavan S, Taylor R, Wolski P (2011) Climate change impacts on hydrology in Africa: case studies of river basin water resources. In: African climate and climate change: physical, social and political perspectives, Springer, Dordrecht, pp 123-153. https://doi. org/10.1007/978-90-481-3842-5_5

Tourian M, Schwatke C, Sneeuw N (2017) River discharge estimation at daily resolution from satellite altimetry over an entire river basin. J Hydrol 546:230-247. https://doi.org/10.1016/j. jhydrol.2017.01.009

Tucker CJ, Dregne HE, Newcomb WW (1991) Expansion and contraction of the Sahara Desert from 1980 to 1990. Science 253(5017):299-300. https://doi.org/10.1126/scien ce. 253.5017 .299

van der Molen M, Dolman A, Ciais P, Eglin T, Gobron N, Law B, Meir P, Peters W, Phillips O, Reichstein M, Chen T, Dekker S, Doubková M, Friedl M, Jung M, van den Hurk B, de Jeu R, Kruijt B, Ohta T, Rebel K, Plummer S, Seneviratne S, Sitch S, Teuling A, van der Werf G, Wang G (2011) Drought and ecosystem carbon cycling. Agric For Meteorol 151(7):765-773. https://doi.org/10.1016/j.agrformet.2011.01.018

van Huijgevoort M (2014) Hydrological drought: characterisation and representation in large-scale models. $\mathrm{PhD}$ thesis, Wageningen University, Wageningen, NL. http://library.wur.nl/WebQu ery/wda/2057611. Accessed 1 Feb 2017

Van Loon AF, Stahl K, Di Baldassarre G, Clark J, Rangecroft S, Wanders N, Gleeson T, Van Dijk AIJM, Tallaksen LM, Hannaford J, Uijlenhoet R, Teuling AJ, Hannah DM, Sheffield J, Svoboda M, Verbeiren B, Wagener T, Van Lanen HAJ (2016) Drought in a human-modified world: reframing drought definitions, understanding, and analysis approaches. Hydrol Earth Syst Sci 20(9):3631-3650. https://doi.org/10.5194/ hess-20-3631-2016

Velicogna I, Kimball JS, Kim Y (2015) Impact of changes in GRACE derived terrestrial water storage on vegetation growth in Eurasia. Environ Res Lett 10(12):124024

Vicente-Serrano SM (2006) Spatial and temporal analysis of droughts in the Iberian Peninsula (1910-2000). Hydrol Sci J 51(1):83-97. https://doi.org/10.1623/hysj.51.1.83

Vicente-Serrano SM, Beguería S, Lorenzo-Lacruz J, Camarero JJ, López-Moreno JI, Azorin-Molina C, Revuelto J, Morán-Tejeda E, Sanchez-Lorenzo A (2012) Performance of drought indices for ecological, agricultural, and hydrological applications. Earth Interact 16(10):1-27. https://doi.org/10.1175/2012EI000434.1

Vörösmarty CJ, Douglas EM, Green PA, Revenga C (2005) Geospatial indicators of emerging water stress: an application to Africa. Ambio

Vörösmarty CJ, Green P, Salisbury J, Lammers RB (2000) Global water resources: vulnerability from climate change and population growth. Science 289(5477):284-288. https://doi.org/10.1126/ science. 289.5477 .284 
Vörösmarty C, Askew A, Grabs W, Barry RG, Birkett C, Döll P, Goodison B, Hall A, Jenne R, Kitaev L, Landwehr J, Keeler M, Leavesley G, Schaake J, Strzepek K, Sundarvel SS, Takeuchi K, Webster F (2001) Global water data: a newly endangered species. EOS Trans Am Geophys Union 82(5):54-58. https://doi. org/10.1029/01EO00031

Wada Y, Bierkens MFP, de Roo A, Dirmeyer PA, Famiglietti JS, Hanasaki N, Konar M, Liu J, Müller Schmied H, Oki T, Pokhrel Y, Sivapalan M, Troy TJ, van Dijk AIJM, van Emmerik T, Van Huijgevoort MHJ, Van Lanen HAJ, Vörösmarty CJ, Wanders N, Wheater H (2017) Human-water interface in hydrological modelling: current status and future directions. Hydrol Earth Syst Sci 21(8):4169-4193. https://doi.org/10.5194/hess-21-4169-2017

Wagner S, Kunstmann H, Bárdossy A, Conrad C, Colditz R (2009) Water balance estimation of a poorly gauged catchment in West Africa using dynamically downscaled meteorological fields and remote sensing information. Phys Chem Earth 34:25-235. https ://doi.org/10.1016/j.pce.2008.04/.002

Wahr J, Molenaar M, Bryan F (1998) Time variability of the Earth's gravity field: Hydrological and oceanic effects and their possible detection using GRACE. J Geophys Res Solid Earth 103(B12):30205-30229. https://doi.org/10.1029/98jb02844

Wald L (1990) Monitoring the decrease of Lake Chad from space. Geocarto Int 5(3):31-36. https://doi.org/10.1080/1010604900 9354266

Washington R, James R, Pearce H, Pokam WM, Moufouma-Okia W (2013) Congo basin rainfall climatology: can we believe the climate models? Philos Trans R Soc Lond B: Biol Sci 368(1625):20120296. https://doi.org/10.1098/rstb.2012.0296

Werth S, White D, Bliss DW (2017) GRACE detected rise of groundwater in the Sahelian Niger River Basin. J Geophys Res Solid Earth. https://doi.org/10.1002/2017JB014845

White WB, Gershunov A, Annis JL, McKeon G, Syktus J (2004) Forecasting Australian drought using Southern Hemisphere modes of sea-surface temperature variability. Int J Climatol 24(15):19111927. https://doi.org/10.1002/joc.1091

WMO (2013) WMO statement on the status of the global climate in 2012. World Meteorological Organization, WMO No.1108. www.wmo.int/pages/prog/wcp/wcdmp/documents/WMO11 08.pdf. Accessed 15 June 2015

WMO (2015). The climate in Africa: 2013. World Meteorological Organization, WMO No.1147. http://www.wmo.int/pages/prog/ wcp/wcdmp/documents/1147_EN.pdf. Accessed 26 Jan 2017

Wouters B, Bonin JA, Chambers DP, Riva REM, Sasgen I, Wahr J (2014) GRACE, time-varying gravity, earth system dynamics and climate change. Rep Prog Phys 77(11):116801. https://doi. org/10.1088/0034-4885/77/11/116801

Xie H, Longuevergne L, Ringler C, Scanlon BR (2012) Calibration and evaluation of a semi-distributed watershed model of Sub-Saharan Africa using GRACE data. Hydrol Earth Syst Sci 16(9):30833099. https://doi.org/10.5194/hess-16-3083-2012

Yang D, Ye B, Kane DL (2004) Streamflow changes over Siberian Yenisei River Basin. J Hydrol 296(1-4):59-80. https://doi. org/10.1016/j.jhydrol.2004.03.017

Yang Y, Long D, Guan H, Scanlon BR, Simmons CT, Jiang L, Xu X (2014) GRACE satellite observed hydrological controls on interannual and seasonal variability in surface greenness over mainland Australia. J Geophys Res Biogeosci 119(12):2245-2260. https://doi.org/10.1002/2014JG002670

Zhang D, Zhang Q, Werner AD, Liu X (2016) GRACE-based hydrological drought evaluation of the Yangtze River Basin, China. J Hydrometeorol 17(3):811-828. https://doi.org/10.1175/ JHM-D-15-0084.1

Zhou L, Tian Y, Myneni RB, Ciais P, Saatchi S, Liu YY, Piao S, Chen H, Vermote EF, Song C, Hwang T (2014) Widespread decline of Congo rainforest greenness in the past decade. Nature 509(7498):86-90. https://doi.org/10.1038/nature13265 